\title{
Intellectual disability rights and inclusive citizenship in South Africa: What can a scoping review tell us?
}

\begin{tabular}{|c|c|}
\hline Authors: & \\
\hline Charlotte Cap & $\mathrm{ri}^{1,2}$ (1) \\
\hline Lameze Abrah & nams s.3 $^{1,3}$ \\
\hline Judith McKen & $\mathrm{zie}^{4} \oplus$ \\
\hline Ockert Coetze & $\mathrm{e}^{1,2}$ \\
\hline Siyabulela Mk & rabile $^{1,3}$ (1) \\
\hline Manuel Sapto & $u^{3}$ (D) \\
\hline Andrew Hoop & $e^{3}$ (D) \\
\hline Peter Smith ${ }^{1,3}$ & \\
\hline Colleen Adnar & $\mathrm{ms}^{1}$ (1) \\
\hline Leslie Swartz & \\
\hline Affiliations: & \\
\hline $\begin{array}{l}{ }^{1} \text { Department } \\
\text { and Mental }\end{array}$ & $\begin{array}{l}\text { of Psychiatry } \\
\text { ealth, }\end{array}$ \\
\hline $\begin{array}{l}\text { University of } \\
\text { South Africa }\end{array}$ & Cape Town, \\
\hline${ }^{2}$ Alexandra Ho & ospital, \\
\hline $\begin{array}{l}\text { Western Cape } \\
\text { South Africa }\end{array}$ & Government, \\
\hline${ }^{3}$ Lentegeur Ps & ychiatric \\
\hline $\begin{array}{l}\text { Hospital, Dep } \\
\text { of Health, Sou }\end{array}$ & $\begin{array}{l}\text { artment } \\
\text { uth Africa }\end{array}$ \\
\hline${ }^{4}$ Department & of Health \& \\
\hline $\begin{array}{l}\text { Rehabilitation } \\
\text { University Of }\end{array}$ & $\begin{array}{l}\text { Sciences, } \\
\text { Cape Town, }\end{array}$ \\
\hline South Africa & \\
\hline${ }^{5}$ Department $\mathrm{C}$ & of Psychology, \\
\hline $\begin{array}{l}\text { Stellenbosch } \\
\text { South Africa }\end{array}$ & University, \\
\hline Correspondin & g author: \\
\hline $\begin{array}{l}\text { Charlotte Capr } \\
\text { charlotte.capri } \\
\text { gov.za }\end{array}$ & i@ \\
\hline Dates: & \\
\hline Received: $30 \mathrm{~N}$ & May 2017 \\
\hline Accepted: 05 & Dec. 2017 \\
\hline Published: 25 & Apr. 2018 \\
\hline Read online: & \\
\hline 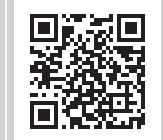 & $\begin{array}{l}\text { Scan this QR } \\
\text { code with your } \\
\text { smart phone or } \\
\text { mobile device } \\
\text { to read online. }\end{array}$ \\
\hline
\end{tabular}

Background: Intellectual disability (ID) is the most prevalent disability in the world. People with intellectual disability (PWID) frequently experience extreme violations of numerous human rights. Despite greater prevalence in South Africa than in high-income countries, most ID research currently comes from the Global North. This leaves us with few contextually sensitive studies to draw from to advance inclusive citizenship.

Objectives: Our scoping review aims to investigate pertinent ID rights issues in South Africa, synthesise quantitative and qualitative studies, and provide a synopsis of available evidence on which to base future work. We aim to clarify key concepts, address gaps in the literature and identify opportunities for further research.

Method: We followed strict eligibility criteria. Medical subject heading terms were entered into seven databases. Seven reviewers worked independently, two per paper. Quantitative and qualitative data extraction forms were designed. We followed Preferred Reporting Items for Systematic Review and Meta-Analysis (PRISMA) guidelines and registered a protocol. An inductive approach enabled a thematic analysis of selected studies.

Results: By following PRISMA guidelines, 82 studies were assessed for eligibility of which 59 were included. Ten sub-themes were integrated into four main themes: the right not to be discriminated against, the right to psychological and bodily integrity, the right to accommodating services and challenges to rights implementation.

Conclusion: People with intellectual disability face compound difficulties when trying to assert their constitutionally entitled rights. This ongoing project requires serious commitment and action. Statutory obligations to nurture every South African's human rights naturally extend to PWID and their supporters who forge ahead in a disabling environment.

\section{Background}

Most people with disabilities live in low-income countries and represent nearly a quarter of the world's poorest people (Emerson 2007; Groce et al. 2011a, 2011b). Against this backdrop, approximately 200 million people live with intellectual disability (ID), making it the world's most prevalent disability (World Health Organization [WHO] \& World Bank 2011).

Medical definitions ascribe ID to deficits in intellectual and adaptive functioning across various domains with onset during the developmental period (AAIDD 2017; American Psychiatric Association [APA] 2017; Crnic et al. 2017). The American Psychiatric Association no longer categorises ID by quantified performances on intellectual ability assessments (APA 2013). Individuals now shift along a continuum of domains that include conceptual, social and practical functioning, and that inform on mild, moderate, severe or profound ID. Supported decisionmaking and individualised care can help people with intellectual disability (PWID) negotiate limitations across compromised domains. Limitations are unlikely to be reversible, but adaptive skills can be developed in suitable environments. This will require types of assistance that vary according to levels of support needs and severity of ID (Figure 1).

Regardless of subjective experiences, the medical model regards impairment as an inherent problem of the individual that is addressed through medico-psychological skill (Nash \& Navias 1992; Mckenzie \& Macleod 2012a; Roy, Roy \& Roy 2012). In South Africa, there are particular dedicated ID treatment sites, and special education is provided in separate schools

How to cite this article: Capri, C., Abrahams, L., McKenzie, J., et al., 2018, 'Intellectual disability rights and inclusive citizenship in South Africa: What can a scoping review tell us?', African Journal of Disability 7(0), a396. https://doi.org/10.4102/ajod.v7i0.396

Copyright: @ 2018. The Authors. Licensee: AOSIS. This work is licensed under the Creative Commons Attribution License. 


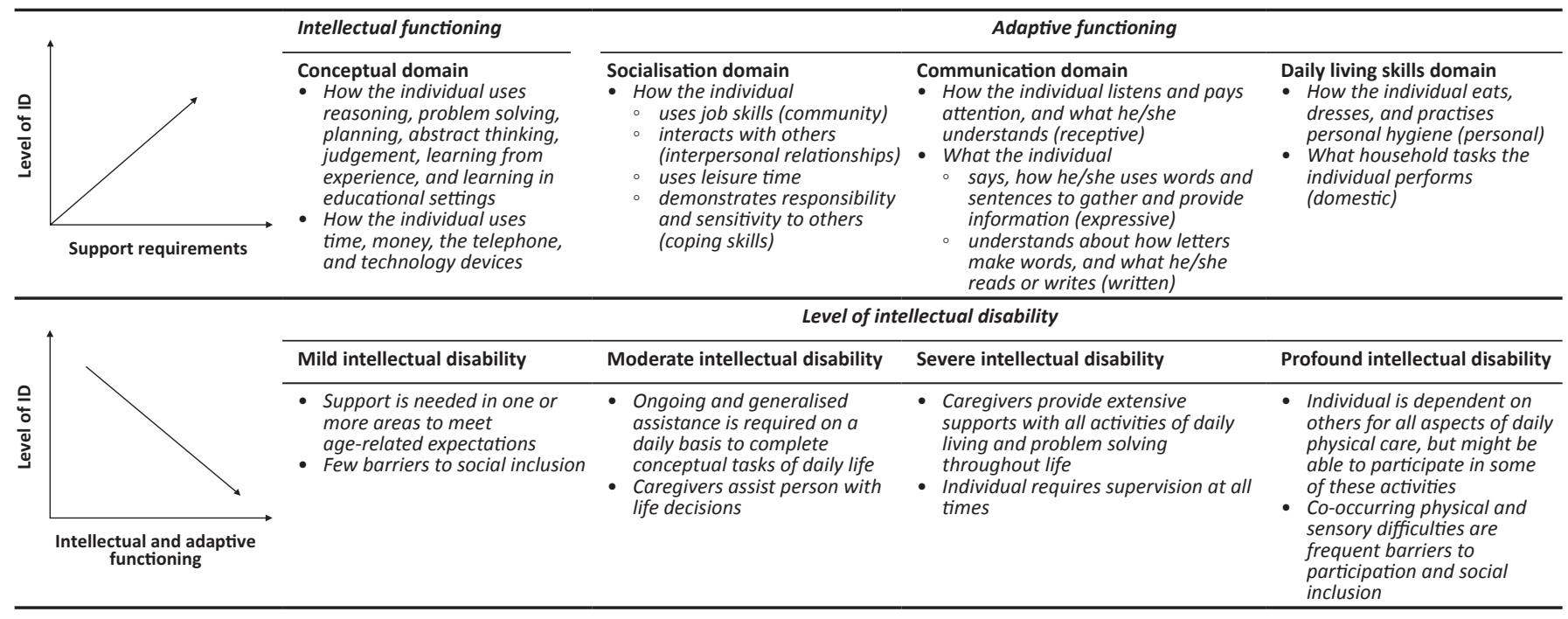

Source: Adapted from American Psychiatric Association (APA), 2013, Diagnostic and statistical manual of mental disorders, 5th edition: DSM-5, American Psychiatric Association, Arlington, TX. ID, intellectual disability.

FIGURE 1: Continuum of support needs according to severity of intellectual disability.

on medico-psychological recommendation (Engelbrecht, Oswald \& Forlin 2006; Mckenzie \& Macleod 2012a).

The social model of disability resists pathologising impairment by separating it from disability (Goodley 2001; Shakespeare 2017; Swartz et al. 2012). Individuals may live with various impairments, but their political and social environments do the disabling. The impairment alone 'is not sufficient for disablement to occur. What disables people - what makes people disabled - is how society responds to the impairments' (Swartz 2010:27-28, own italics). Rather than locating disability in the person, it is viewed as the result of interactions among disabling physical environments and unequal social relationships that further encumber impairment (Young \& Berry 2016). It separates bodily impairment from a sociopolitical unwillingness to accommodate an individual's needs (Mckenzie \& Macleod 2012a; Young \& Berry 2016). The social model of disability does not escape criticism either. Disability might be a function of physical and socio-political environments, but competence can be interactively achieved among individuals and enabling environments (Mckenzie \& MaCleod 2012b; Pillay 2003). In this way, individuals are enabled and environments become impairment competent. Moreover, some disabled people are proud of bodies marked by prejudice and chipped away by the norms of a predominantly able-bodied world (Hughes et al. 2017).

By synthesising the medical and social models, the WHO (2002) offers an integrative bio-psycho-social model of disability. The International Classification of Functioning, Disability and Health (ICF) frames biological, individual and social aspects of health as inseparable. Disability as a consequence of disease or socio-political ignorance shifts to a site of interacting health, environmental and personal factors (Mji et al. 2017). At any given time and in any combination, these factors can facilitate or hamper a person's functioning (Selb 2017).
Finally, if we appreciate disability as fluid and situational, we are no longer polarised or opposed as enabled or disabled, but occupy different spaces on the continuum of 'changing states of impairment and health' (Swartz et al. 2012:1). By drawing on one another's experience of disability and ablebodiedness, it becomes possible for us to shift and meet along this continuum and reach a 'richer understanding' of living with ID (Swartz et al. 2012:8).

The issue of societal inclusion and exclusion of PWID on psycho-medical, socio-political or accessibility grounds touches on core questions of rights claims, justice, citizenship, equality, resources and protections. People with intellectual disability may have limitations in advocating for themselves and ensuring that their best interests are prioritised. Not affording PWID support or opportunity to contribute to policies that directly impact their lives can be viewed as morally abusive (Kittay 2009:620). Disenfranchising PWID maintains vulnerability to exploitation, marginalisation and inequality in systems where the distribution of care and services hardly occurs in their favour and very seldom adequately (Adnams 2010). Without appropriate supportive decision-making or opportunity to assert access to recourse with assistance, PWID are subjugated to whatever form care may take and at risk of abuse and neglect (Makgoba 2016).

Driven by misconception, fear and lack of knowledge, discrimination against PWID can result in isolation, segregation, stigma and death (Byrne 2017; Flores 2017; Lindau et al. 2017; Maclean et al. 2017; Makgoba 2016; Thornicroft et al. 2007; Wissink et al. 2017). Only 2 out of every 100 children with disabilities receive schooling in developing countries (Cramm et al. 2013; Du Plessis 2013). Compared to the general population and other disability groups, PWID are more often unemployed or underemployed because of low expectations of competence ('they' can't do much) and high expectations of problems ('they' are difficult to work with) (Carvalho-Freitas \& Stathi 2017; Merrells, Buchanana \& Waters 2017; WHO 2011; Wilson et al. 2017). 


\section{A South African setting}

South Africa exceeds ID prevalence in high-income countries (Maulik et al. 2011; McKenzie 2016; Tomlinson et al. 2014). To this point, foetal alcohol spectrum disorder (FASD) is an easily preventable cause of ID, but South Africa's prevalence rate of $6 \%-9 \%$ is one of the world's highest (Adnams 2010; De Vries et al. 2013; Roozen et al. 2016; Urban et al. 2008).

Accurate South African data on ID prevalence among 2-9-year-old children were last gathered in the 1990s (Christianson et al. 2002; Kromberg et al. 1997, 2008). During the 2011 national census, ID was not directly measured, and statistics on children with disabilities aged 0-4 years were not profiled (Statistics South Africa [SSA] 2014). Current accurate South African ID data are rare (Du Plessis 2013; Fujiura, Rutkowski-Kmitta \& Owen 2010). At last count, $3.2 \%$ of people aged 5 years and older have mild and $1 \%$ of people have severe difficulties 'in remembering or concentrating' (SSA 2014:34).

Despite ratifying the United Nations Convention on the Rights of Persons with Disabilities (UNCRPD) (The United Nations [UN] 2006) a decade ago, South Africa's dualist legal system has yet to assimilate the international conventions into domestic legislation on behalf of PWID (Huus et al. 2015). Lawmakers' lack of understanding of what 'intellectual disabilities actually mean' was even officially gazetted in parliament (Department of Social Development [DSD] 2015, own italics). Additionally, although the White Paper on the Rights of Persons with Disabilities (DSD 2016) commits to PWID, it makes little mention of how these commitments will be implemented or monitored (De Vries et al. 2013; Drew et al. 2011; Kopel 2017; Officer \& Shakespeare 2013; Roy et al. 2012).

Because of shortage of educational programmes for children with intellectual disability (CWID), parents in countries like South Africa easily become unpaid caregivers because care burdens and lack of support hinder their pursuit of employment (Geiger 2012; Mckenzie \& McConkey 2016). Being out of school also limits exposure of CWID to formal teaching on sexual health programmes (Rohleder \& Swartz 2009; WHO 2011). This is problematic, because more than two-thirds of adolescents with ID are at risk of sexual abuse before they turn 18 , whereas up to $83 \%$ of women and $32 \%$ of men with ID are at increased risk of being sexually assaulted in their lifetime (Byrne 2017; Peckham 2007).

Other frequently violated rights of PWID in South Africa pertain to physical abuse, exclusion, barriers to accessing medical and mental health services, involuntary confinement, denial of marriage or parenting, financial exploitation, unemployment, occupational restrictions and living safely outside of institutions (Drew et al. 2011; Erasmus, Bornman \& Dada 2016). These rights are violated in public, family 1.The estimated South African population is 55908865 (World Bank 2017), implying
that more than 2000000 individuals may be living with difficulties 'in remembering or concentrating'. homes, places of education and work, care centres, health care settings, police stations, courts and civic offices (Drew et al. 2011).

As yet, we know little about South African evidence-based studies on which to build better ID rights practice. Most ID research comes from high-income countries where PWID enjoy various government and community supports but is not always applicable to settings in which most PWID live (Glicksman et al. 2017; Groce et al. 2011a, 2011b; McKenzie, McConkey \& Adnams 2013a; Robertson et al. 2012). For this reason, we aim to investigate pertinent South African ID rights issues, clarify key concepts, synthesise quantitative and qualitative studies and provide a synopsis of existing evidence (Arksey \& O’Malley 2005; Daudt, Van Mossel \& Scott 2013; Harden 2010; Peters et al. 2015).

\section{Aim}

The primary aim of our scoping review was to collect all literature published in peer-reviewed journals on ID rights in South Africa over the past 25 years (1992-2017). We set out to study the ID advocacy, awareness and rights promotion research; describe outcomes of studies on realising human rights entitlements; and identify publications that address claims to citizenship of South African PWID. Following Peters et al.'s (2015) suggestions for scoping reviews, our objectives were guided by questions specific to this study:

- What do we know about the state of human rights of PWID in South Africa?

- Are there barriers jeopardising rights realisation?

- Are PWID participating in socio-political lives of communities?

- Is rights advocacy needed?

- Which studies can we use to address these questions?

We also aim to identify areas for future investigation by highlighting gaps in the available research.

\section{Method}

We followed the Preferred Reporting Items for Systematic Review and Meta-Analysis (PRISMA) guidelines and registered a protocol with PROSPERO (CRD42016036100). An inductive approach accommodated thematic analyses of selected studies.

\section{Eligibility}

Included studies are on rights of PWID in South Africa published between 1992 and 2017. Research sites and participants are in South Africa. Comparative country studies on ID had to include South Africa (World Bank 2017). Eligibility criteria for inclusion in this review are summarised in Table 1.

Reviewer panel consensus minimised study selection bias by resolving issues like the eligibility of studies on FASD and autism spectrum disorder (ASD). Intellectual disability 
TABLE 1: Eligibility criteria for inclusion of studies in this scoping review.

\begin{tabular}{|c|c|}
\hline Inclusion criteria & Exclusion criteria \\
\hline Children and adults with ID & $\begin{array}{l}\text { Studies on disability but not ID } \\
\text { Studies on co-occurring presentations in } \\
\text { which ID is not necessarily included by } \\
\text { definition, or syndromes in which ID is a } \\
\text { variable outcome }\end{array}$ \\
\hline Human rights & Human rights study is not on rights of PWID \\
\hline $\begin{array}{l}\text { Research sites and participants are } \\
\text { in South Africa }\end{array}$ & Study is not on South Africa \\
\hline $\begin{array}{l}\text { Peer-reviewed academic journal } \\
\text { articles }\end{array}$ & $\begin{array}{l}\text { Study not in blind peer-reviewed journal } \\
\text { (e.g. in a predatory journal) }\end{array}$ \\
\hline Published between 1992 and 2017 & Studies outside time span \\
\hline Full text available & $\begin{array}{l}\text { Full-text unavailable (please see 'Information } \\
\text { sources') }\end{array}$ \\
\hline English & Languages other than English \\
\hline $\begin{array}{l}\text { Studies on ID in other unequal } \\
\text { societies had to include South Africa } \\
\text { (World Bank 2017) }\end{array}$ & $\begin{array}{l}\text { Studies on ID in Africa and southern Africa } \\
\text { but not South Africa } \\
\text { Irrelevant database returns } \\
\text { (e.g. South Carolina) }\end{array}$ \\
\hline
\end{tabular}

ID, intellectual disability; PWID, people with intellectual disability.

is not required for an FASD diagnosis, and low or average intellect is actually more common in FASD (Royal College of Psychiatrists [RCP] 2001). Studies with participants with FASD and low or average intellect were thus excluded from this review (RCP 2001).

Although developmental disorders and ID coexist and share associations, ASD may not have caused ID and not all individuals with ASD have ID (RCP 2001). Conversely, studies that included, for example, people with Down syndrome (DS) and phenotypical ID were eligible for review (RCP 2001).

\section{Information sources}

We searched seven databases (Web of Science, PubMed, Scopus, ERIC, Africa-Wide Information/NiPAD, African Journal Archive and African Index Medicus) to increase the likelihood of locating South African publications among international studies. Electronically unavailable records were hand searched, authors were contacted or subject librarians at Stellenbosch University were approached. Backward and forward citation searches identified additional studies. The last search ran on 31 August 2017 which was also the author contact cut-off date.

\section{Search strategy}

Data were sought for outcome, setting and participants by using medical subject headings (MeSH) terms (Box 1) as per systematic scoping review practice. ${ }^{2}$ Searches were sensitised for time span (1992-2017) and English as publication language. English is a compulsory subject in South African schools and the language of business and government. It is also the preferred instruction medium in most tertiary institutions from which ID practitioners and researchers graduate (Dictionary Unit for South African English 2016; Donohue, Bornman \& Granlund 2015).

2.MeSH (Medical Subject Headings) is the National Library of Medicine (NLM) controlled vocabulary thesaurus used for indexing articles. It facilitates replicability and consists of sets of terms naming descriptors in a hierarchical structure. Articles are associated with a set of MeSH terms that describe the content of the article.
BOX 1: Search by medical subject heading terms.

- TOPIC: 'Intellectual disability' OR 'developmental disabilities'

- AND TOPIC: 'South Africa' (includes Republic of South Africa)

- AND TOPIC: 'Adult'(includes aged, middle aged, young adult, aged 80 and over, frail elderly) OR 'adolescent' OR 'child'(includes child, preschool) OR 'infant' (includes newborn)

- AND TOPIC: 'Human right' (includes rights, human)

TABLE 2: Critical appraisal checklists.

\begin{tabular}{ll}
\hline Type of study & Critical appraisal checklist \\
\hline $\begin{array}{l}\text { Action research studies } \\
\text { Can be (non) randomised and/or } \\
\text { (non) controlled }\end{array}$ & $\begin{array}{l}\text { Action research designs (Greenhalgh et al. } \\
\text { 2008:242-244) }\end{array}$ \\
$\begin{array}{l}\text { Case control studies } \\
\text { Cohort studies }\end{array}$ & Case control study (CASP) \\
$\begin{array}{l}\text { Cross-sectional studies } \\
\text { Diagnostic studies }\end{array}$ & Cohort study (CASP) \\
Mixed-method case studies & Cross-sectional study (CASP) \\
\hline $\begin{array}{l}\text { Opinion and analysis } \\
\text { Prevalence studies }\end{array}$ & $\begin{array}{l}\text { Mixed-methodology case study (HEBW) } \\
\text { (Greenhalgh et al. 2008:239) }\end{array}$ \\
$\begin{array}{l}\text { Qualitative case studies } \\
\text { Qualitative studies }\end{array}$ & Narrative, expert opinion and text (JBI) \\
Quantitative case studies & Studies reporting prevalence data (JBI) \\
Randomised controlled trials & Qualitative case study (Atkins \& Sampson 2002) \\
Reviews & Qualitative studies (SURE) \\
Single participant case designs & Quantitative case study (CEBMa) \\
Medical case reports & Review studies (PRISMA) \\
\hline
\end{tabular}

\section{Study selection}

In an attempt to minimise risk of bias across studies that may affect the overall review results, seven reviewers worked independently, two per paper, to assess each study according to the review's eligibility criteria (C.C., O.C., J.M., L.A., M.S., S.M., A.H.). Three experts were available for data verification (P.S., C.A., L.S.). Future systematic reviewers can critically appraise individual bias within studies by means of checklists suitable to study design and available in the public domain as offered in Table 2. Individual studies can be assessed for evidence of bias reduction by purposeful design or by ways in which authors acknowledge any bias that might affect individual study results.

\section{Data collection}

Data extraction forms for quantitative and qualitative studies used PICOS (Population, Intervention, Comparison, Outcome, Study design) and SPIDER (Sample, Phenomenon of Interest, Design, Evaluation, Research type) elements, respectively (Cooke, Smith \& Booth 2012) (Tables 3a and 3b).

\section{Ethical considerations}

Although this systematic review did not require ethical clearance, it is based on literature sought for a research study that obtained ethical clearance from the Health Research Ethics Committee of Stellenbosch University's Faculty of Health Sciences (Federal Wide Assurance Number: 00001372, Institutional Review Board Number: IRB0005239). 
TABLE 3a: Examples of data extraction forms - Population, Intervention, Comparison, Outcome, Study design: For quantitative studies.

\begin{tabular}{|c|c|c|c|c|}
\hline First author & $\begin{array}{l}\text { Population, study } \\
\text { size and setting }\end{array}$ & Intervention, comparison, and/or effect size & Outcome & Study design \\
\hline Ali (2015) & $\begin{array}{l}n=191 \\
\text { Cape Town }\end{array}$ & $\begin{array}{l}\text { Perceived stigma of intellectual disability tool (South African version). } \\
\text { Significant interaction between ethnic group and level of intellectual } \\
\text { disability }(F=3.74, p=0.01) \text {. Lower age significantly associated with } \\
\text { stigma }(p=0.02) \text {. }\end{array}$ & $\begin{array}{l}\text { Younger people with intellectual disability } \\
\text { and those with mild intellectual disability } \\
\text { from black ethnic communities experience } \\
\text { more stigma. }\end{array}$ & $\begin{array}{l}\text { Case study } \\
\text { (Quantitative) }\end{array}$ \\
\hline Saloojee (2007) & $\begin{array}{l}n=156 \\
\text { Orange Farm, } \\
\text { Soweto, Gauteng }\end{array}$ & $\begin{array}{l}\text { Screening questions, clinical observation, semi-structured interviews. } \\
\text { Children with motor impairments were more likely to receive } \\
\text { rehabilitation than those with intellectual impairment }(p<0.0001) \text {. }\end{array}$ & $\begin{array}{l}\text { Little evidence found of cooperation } \\
\text { between the health, education and social } \\
\text { development departments. }\end{array}$ & $\begin{array}{l}\text { Case study } \\
\text { (Quantitative) }\end{array}$ \\
\hline
\end{tabular}

TABLE 3b: Examples of data extraction forms - Sample, Phenomenon of Interest, Design, Evaluation, Research: For qualitative studies.

\begin{tabular}{|c|c|c|c|c|c|}
\hline First author & Sample and setting & Phenomenon of interest & Design & Evaluation & Research type \\
\hline Engelbrecht (2003) & $\begin{array}{l}n=55 \\
\text { Gauteng and the } \\
\text { Western Cape }\end{array}$ & Inclusion (education services) & $\begin{array}{l}\text { Questionnaire, in-depth } \\
\text { structured interviews }\end{array}$ & $\begin{array}{l}\text { Including learners with intellectual disability in } \\
\text { mainstream classes is stressful for teachers. }\end{array}$ & $\begin{array}{l}\text { Case study } \\
\text { (Mixed method) }\end{array}$ \\
\hline McKenzie (2012a) & $\begin{array}{l}n=85 \\
\text { East London, Eastern } \\
\text { Cape }\end{array}$ & Rights discourses & Q-methodology & $\begin{array}{l}\text { The three rights claims (participation, special services } \\
\text { and protection) should be re-examined through the } \\
\text { lens of an ethics of care that enables participation, } \\
\text { and that reconsiders reciprocity and interdependence. }\end{array}$ & $\begin{array}{l}\text { Grounded } \\
\text { theory study }\end{array}$ \\
\hline
\end{tabular}

\section{Results}

By following PRISMA guidelines, 156 records were identified overall. Ninety-six studies remained after deleting duplicates. Two reviewers screened each abstract resulting in 14 exclusions. Eighty-two studies were assessed for eligibility of which 59 were included for qualitative synthesis (Figure 2).

Characteristics of included papers $(n=59)$ are summarised in Table 4 in reference to alphabetically ordered first author, topic, study design and outcome. They are discussed in more detail below. Studies made use of quantitative $(n=26)$, qualitative $(n=31)$ and mixed-methods $(n=2)$ designs.

Individual study findings were synthesised into 10 subthemes. These were then integrated into four main themes (Table 5). The first main theme speaks to the right not to be discriminated against $(n=36)$ and addresses inclusive education, inclusive communication and the right to be understood, acknowledgement of competence and capacity to be included, and socio-political participation and inclusive citizenship. The second theme addresses the right to psychological and bodily integrity $(n=11)$ in terms of protection against abuse, and the right of abuse victims to appropriate treatment. Thirdly, the right to be accommodated $(n=8)$ speaks to availability of appropriate services and subsequent access to these services. Finally, main theme four touches on challenges to rights realisation $(n=4)$, warns of barriers to support and considers obstacles to rights implementation.

The majority of included studies pertain to the right not to be discriminated against $(n=36)$ with inclusive education ( $n=14)$ and acknowledgement of competence and capacity $(n=13)$ also enjoying focus. The right to psychological and bodily integrity $(n=11)$ enjoyed slightly more research interest than the right to be accommodated $(n=8)$ and challenges to realisation of rights $(n=4)$.

Rights issues that received the least amount of research attention throughout the review period include the right to be understood $(n=4)$ and availability of appropriate services $(n=2)$. Results show that the right to socio-political participation and inclusive citizenship requires urgent investigation $(n=1)$.

The Bill of Rights (Act 108 of 1996) enshrines universal dignity (s7.1), equality (s9.2), protection against discrimination by persons or the state on grounds of disability (s9.3), life (s11), bodily and psychological integrity (s12.2), voting in elections (s19.3a), health care (s27.1a) and primary and secondary school education (s29.1a) (Republic of South Africa [RSA] 1996). Although the Constitution and Bill of Rights still guides South Africa's post-democratic growth, ID remains excluded from socio-political discourses on equity and transformation. If meaningful transformation is only reached by including the whole of society, excluding PWID risks further discrimination and rights abuses of millions of South Africans.

\section{Right to not be discriminated against}

The right to inclusive education, inclusive communication, competence and capacity, and socio-political participation speaks to issues of discrimination $(n=36)$.

Popular belief that PWID are inferior opens them up to abuse and exploitation (Phasha \& Myaka 2014). As vulnerable targets of stigmatisation and disenfranchisement, such discrimination is hard to overcome without support and advocacy (Carey 2003; Kamga 2016). Younger adults with ID from lower socio-economic areas who also have physical disabilities experience additional stigma (Ali et al. 2015). Disability exacerbates complicated issues of race and identity in South Africa, and black individuals with mild ID experience more stigma than white and mixed race PWID (Ali et al. 2015).

\section{Inclusive education}

The Bill of Rights entitles children and adults to basic education (s29.1a, RSA 1996). South Africa also interpreted and used international declarations to transition towards greater inclusion in education. The education system was meant to adjust in ways that would accommodate diverse learners' needs as inclusively as possible (Engelbrecht et al. 2003). 


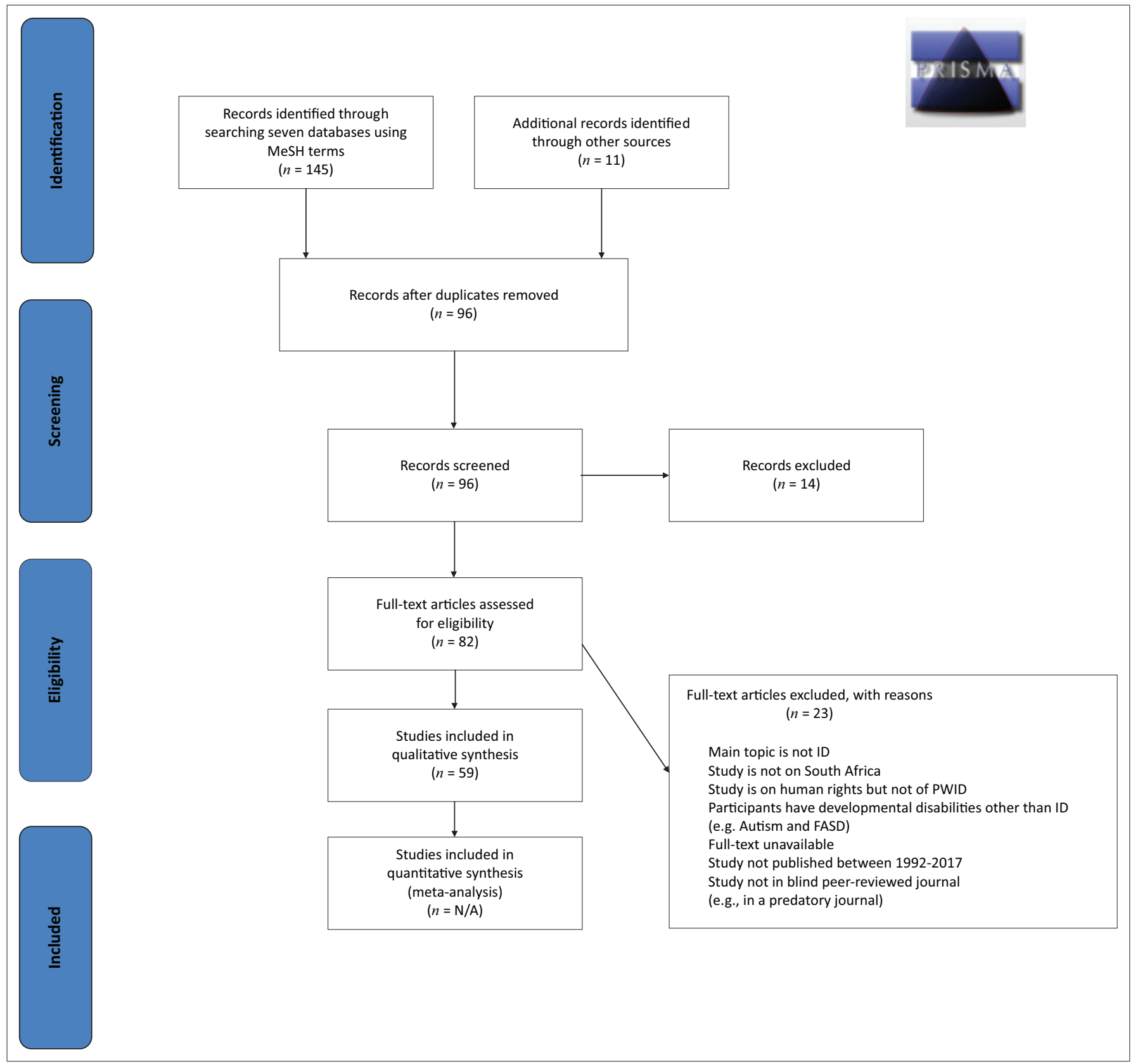

Source: Moher, D., Liberati, A., Tetzlaff, J., Altman, D.G. \& The PRISMA Group, 2009, 'Preferred reporting items for systematic reviews and meta-analyses: The PRISMA statement', PLoS Medicine 6(7), e1000097. https://doi.org/10.1371/journal.pmed1000097

For more information, visit http://www.prisma-statement.org/

MeSH, medical subject headings; ID, intellectual disability; PWID, people with intellectual disability; FASD, foetal alcohol spectrum disorder

FIGURE 2: Preferred reporting items for systematic review and meta-analysis flow diagram - Results of study selection.

After the Western Cape High Court ${ }^{3}$ was petitioned on claims to education in 2011, the state was ordered to ensure - within reason - affordable access to adequate education for children with severe and profound ID (CSPID) (Du Plessis 2013; Mckenzie et al. 2017). The White Paper on the Rights of Persons with Disabilities (2016) now reinforces the enrolment of children with any severity of ID previously refused access (DSD 2016). Although the right to basic education is immediate, the state can still exclude PWID from educational settings by arguing reasonable grounds (Kruger 2015; Ngwena 2013). Up to 260000 school-going aged children

3.Western Cape Forum for Intellectual Disability (WCFID) v Government of the Republic of South Africa and Another (2011) SA 87 (Western Cape High Court, Cape Town). with disabilities in South Africa were not enrolled in 2001 by 2009, the figure amounted to 467005 (Du Plessis 2013).

The state discriminates against CSPID, in particular, by using severity of impairment to disqualify them from compulsory education (Ngwena 2013). Most enrolled children with mild and moderate ID are separated into schools for learners with special educational needs (LSEN), whereas CSPID are further segregated in special care centres (Donohue \& Bornman 2014; Spangenberg et al. 2016). By such segregation, educational policy and schooling for CSPID has become a site of disablement and degradation (Geiger 2012; Human Rights Watch 2015; Ngwena \& Pretorius 2012). 
TABLE 4: Characteristics of included studies $(n=59)$

\begin{tabular}{|c|c|c|c|}
\hline & First author & Topic & Study design \\
\hline 1. & Ali (2015) & $\begin{array}{l}\text { Right not to be discriminated } \\
\text { against }\end{array}$ & Case study (Quantitative) \\
\hline 2. & Bornman (2016) & Protection against abuse & Multi-method study (Qualitative) \\
\hline 3. & Bornman (2011) & The right to be understood & Action research (Qualitative) \\
\hline 4. & Bornman (2002) & The right to be understood & Case study (Mixed method) \\
\hline 5. & Bornman (1996) & The right to be understood & Case study (Quantitative) \\
\hline 6. & Calitz (2011) & $\begin{array}{l}\text { Bodily and psychological } \\
\text { integrity }\end{array}$ & Opinion and analysis (Qualitative) \\
\hline 7. & Calitz (2014) & Protection against abuse & Case study (Quantitative) \\
\hline 8. & Calitz (2007) & $\begin{array}{l}\text { The right to competence and } \\
\text { capacity }\end{array}$ & Case study (Quantitative) \\
\hline 9. & Capri (2012) & Access to services & Opinion and analysis (Qualitative) \\
\hline 10. & Dada (2013) & Communicative inclusion & Case study (Quantitative) \\
\hline 11. & Dickman (2005) & $\begin{array}{l}\text { Bodily and psychological } \\
\text { integrity }\end{array}$ & Case study (Quantitative) \\
\hline 12. & Donohue (2014) & Inclusive education & Opinion and analysis (Qualitative) \\
\hline 13. & Donohue et al. (2014) & Risks to realisation of rights & Case study (Quantitative) \\
\hline 14. & Donohue (2015) & Realising inclusive education & Case study (Quantitative) \\
\hline 15. & Donohue et al. (2015) & Risks to realisation of rights & Case study (Quantitative) \\
\hline 16. & Du Plessis (2013) & Realising inclusive education & Opinion and analysis (Qualitative) \\
\hline 17. & Engelbrecht (2003) & Realising inclusive education & Case study (Mixed method) \\
\hline 18. & Erasmus (2016) & Realising inclusive education & Case study (Quantitative) \\
\hline 19. & Geiger (2012) & $\begin{array}{l}\text { Right not to be discriminated } \\
\text { against }\end{array}$ & $\begin{array}{l}\text { Participatory learning and action } \\
\text { approach, and iterative process } \\
\text { (Qualitative) }\end{array}$ \\
\hline 20. & Hall (2016) & Realising inclusive education & Case study (Qualitative) \\
\hline 21. & Huus (2015) & Realising inclusive education & Case study (Quantitative) \\
\hline 22. & Huus (2016) & Realising inclusive education & Case study (Quantitative) \\
\hline 23. & Kock (2012) & $\begin{array}{l}\text { Right not to be discriminated } \\
\text { against }\end{array}$ & Case study (Quantitative) \\
\hline 24. & Kramers-Olen (2016) & $\begin{array}{l}\text { Right to psychological and bodily } \\
\text { integrity }\end{array}$ & Literature review (Qualitative) \\
\hline
\end{tabular}

Outcome

Younger people with ID and those with mild ID from black ethnic communities experience more stigma.

Development of social stories to use in a sexuality and relationship training programme for women with ID.

Development of communication boards.

Nurses' knowledge and skills in dealing with ID, PWID and caregivers is inadequate. Need for skills training identified.

$38 \%$ prevalence rate of non-speaking CWID. settings.

Burden of evidence to secure convictions rests on investigations and physical evidence.

It is possible for a person with ID to be triable and accountable.

Excluding PWID from participating in research can be a human rights violation. Symbols used were relatively iconic to participants. Iconicity may be enhanced by modifying them according to age, culture and language. ID specific interventions have a direct impact on justice for complainants with ID who have been sexually abused.

Lack of clear policy is the most significant constraint to inclusive education. Risk influences access to resources for CWID.

Providing teachers with inclusive training could positively influence their attitudes.

Household size mediated by poverty has communication outcomes for CWID.

South African out-of-school figures for CSPID are consistent with other developing countries in that only $2 \%$ of CSPID receive any schooling. Including learners with ID in mainstream classes is stressful for teachers. Education and safety of most concern to parents.

Centre-based carer training urgent in low-income settings.

Identified actions that mainstream schools can execute to enable the resilience of included adolescents with ID.

Socio-economic factors affect similar self-raters and proxy raters answers.

Urban caregivers more aware of various rights than rural counterparts.

Adults with ID in SA are stigmatised.

Highlights tension between protecting PWID from exploitation, and the promotion of sexual autonomy. Competency to consent to sexual acts remains an issue.

25. Kruger (2015) Realising inclusive education Opinion and analysis (Qualitative)

Outcome of substantive equality can be undermined by court's consideration of reasonableness. South African education policy is insufficient to effect substantive equality.

26. McKenzie (2016) Right not to be discriminated Case study (Qualitative)

PWID require care; protection from crime, violence and abuse; help with independence, accessing resources, and community integration.

Improved support services appropriate to the resources in LAMIC are needed especially when existing FCGs are no longer able to provide care.

27. McKenzie et al. (2016) Risks to realisation of rights Case study (Qualitative) The Interactive Discourse appears to be related to dynamic, environmenta conceptions of disability where competence is built through social interaction.

Grounded theory study (Qualitative)

Facilities have limited access to general health care. Little emphasis placed on competence and quality of life. Employment and vocational training is neglected. Access to support is limited but emerging.

29. McKenzie et al. Right to access services and be Case study (Quantitative) (2013b) accommodated

Pay closer attention to awareness raising (Article 8, UNCRPD) for community integration. Forms of participation per Articles 29 and 30 were not evident in integration.
the study.

McKenzie et al. Right to access services and be Case study (Quantitative) (2013c) accommodated

31. McKenzie (2012a)

The right to competence and

Grounded theory study

The three rights claims (participation, special services and protection) should be re-examined through the lens of an ethics of care that enables should bere-examined through the lens of an ethics of care that enables psychological gaze regulates educational experience of CWID.

Medico-psychological gaze maintains unilateral disability expertise and inherent power relations, but PWID are not one-sided recipients of care and special services.

Grounded theory study (Qualitative)

\begin{tabular}{|c|c|c|c|}
\hline 33. & Nash (1992) & $\begin{array}{l}\text { The right to competence and } \\
\text { capacity }\end{array}$ & Opinion and analysis (Qualitative) \\
\hline 34. & $\mathrm{Nel}(2007)$ & $\begin{array}{l}\text { The right to competence and } \\
\text { capacity }\end{array}$ & Action research (Qualitative) \\
\hline 35. & Nel (2011) & Realising inclusive education & Action research (Qualitative) \\
\hline 36. & Ngwena (2012) & Realising inclusive education & Opinion and analysis (Qualitative) \\
\hline
\end{tabular}

Main issues involved in sterilisation include a valid assessment of the level of $D$, availability of alternative means of fertility control, and complex ethical factors.

Emphasising the coaching modality, a single-unit longitudinal approach ensured successful transition.

Differential learning can realise the right to life.

Differences in embodied ability should be understood in a non-hierarchical and non-separatist manner. Equality jurisprudence must rethink the meaning of difference in order to guarantee inclusive citizenship.

37. Ngwena (2013)

38. Petersen (2004)

Realising inclusive education

Right to access services and be

Opinion and analysis (Qualitative)

Case study (Quantitative)
State ambivalence towards inclusive education is demonstrated.

Demand for ID services are great. 
TABLE 4 (Continues...): Characteristics of included studies $(n=59)$

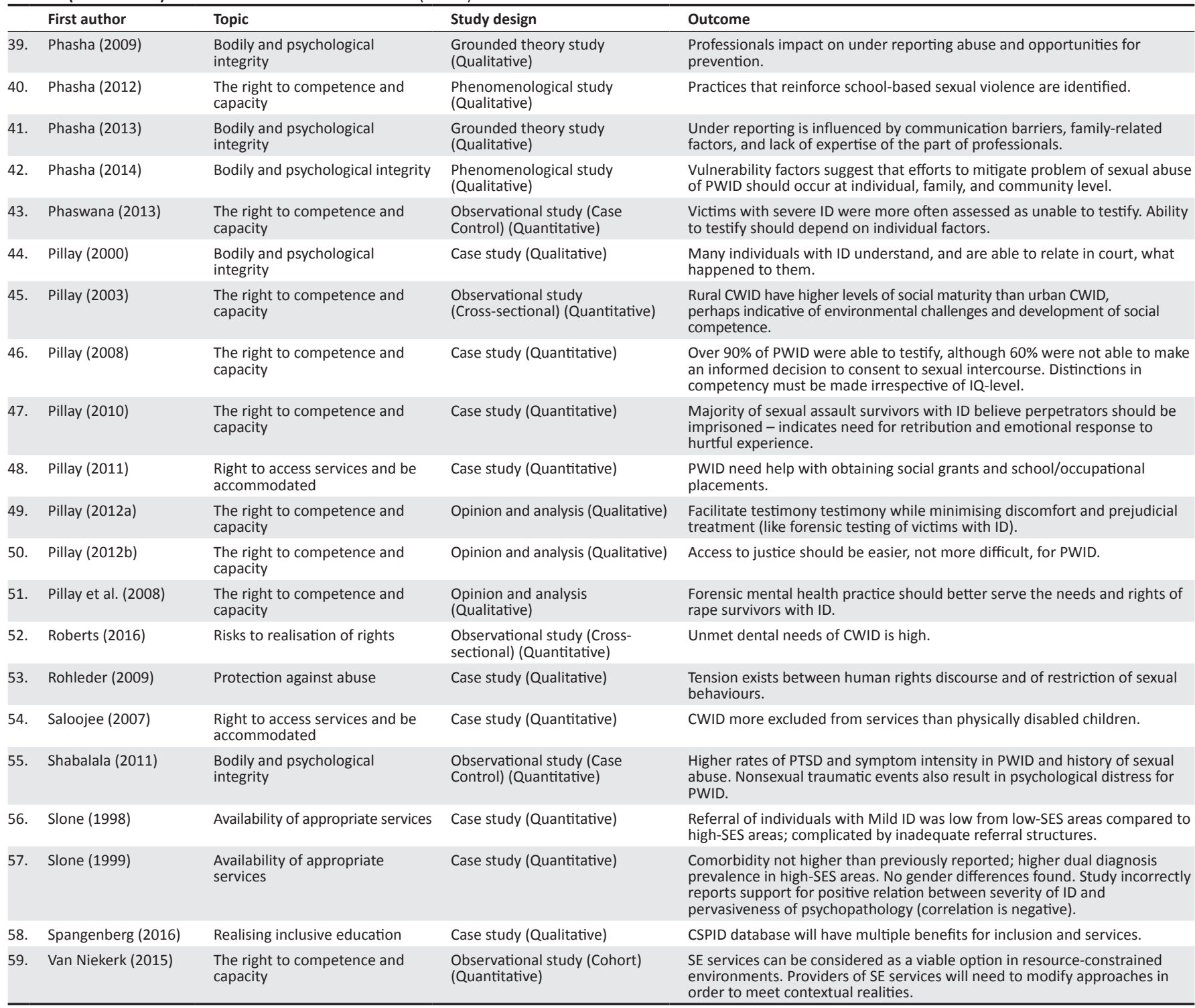

ID, intellectual disability; PWID, people with intellectual disability; CWID, children with intellectual disability; CSPID, children with severe and profound intellectual disability; PTSD, post-traumatic stress disorder; UNCRPD, United Nations Convention on the Rights of Persons with Disabilities; LAMIC, low- to middle-income countries; FCG, family caregivers; SES, socioeconomic status; SE, stress disorder; UNCRPD,
supported employment.

TABLE 5: Themes and sub-themes

\begin{tabular}{ll}
\hline Themes & Sub-themes \\
\hline $\begin{array}{l}\text { Right not to be } \\
\text { discriminated against } \\
(n=36)\end{array}$ & $\begin{array}{l}\text { Inclusive education } \\
\text { Inclusive communication (the right to be understood) }\end{array}$ \\
$\begin{array}{l}\text { Acknowledgement of competence and capacity to be } \\
\text { included } \\
\text { Socio-political participation (inclusive citizenship) }\end{array}$ \\
$\begin{array}{l}\text { Right to psychological and } \\
\text { bodily integrity ( } n=11)\end{array}$ & $\begin{array}{l}\text { Protection against abuse } \\
\text { Right of victims of abuse to appropriate treatment }\end{array}$ \\
$\begin{array}{l}\text { Right to be accommodated } \\
(n=8)\end{array}$ & $\begin{array}{l}\text { Availability of appropriate services } \\
\text { Access to available services }\end{array}$ \\
$\begin{array}{l}\text { Challenges to realisation } \\
\text { of rights }(n=4)\end{array}$ & $\begin{array}{l}\text { Barriers to necessary levels and kinds of support } \\
\text { Obstacles to rights implementation }\end{array}$ \\
\hline
\end{tabular}

Few urban CSPID under 4 years attend special care centres (Spangenberg et al. 2016), and even fewer do in rural areas where prevalence is higher but care centres in shorter supply (Huus et al. 2016). Although rural and urban caregivers are equally aware of rights to education $(p=0.001)$, urban caregivers believe more firmly that CWID have rights $(p<0.001)$ (Huus et al. 2016).

Including PWID in non-discriminatory educational communities is complicated. People with intellectual disability have vastly diverse educational needs and meeting them equitably will require the entire South African mainstream school-LSEN-care centre split system to change (Engelbrecht et al. 2003; Erasmus et al. 2016; Hall \& Theron 2016). Adapting curricula for CWID in regular or mainstream classes will demand effort and perhaps impact negatively on educators' views of inclusion, but training and support can facilitate inclusive attitudes (Donohue \& Bornman 2015; Engelbrecht et al. 2003; Hall \& Theron 2016; Mckenzie \& Macleod 2012b). Addressing diverse educational needs can lead to flexible teaching of CWID in regular schools, accessible assessment practices and learning life preserving skills 
(Mckenzie \& Macleod 2012b; Nel, Kempen \& Ruscheinski 2011; Rohleder \& Swartz 2009).

\section{Inclusive communication}

Augmentative and alternative communication (AAC) can support PWID who have difficulties with conventional communication in various settings (Bornman \& Alant 1996, 2002; Bornman et al. 2011; Dada et al. 2013). Making little effort to understand what PWID who have communication difficulties are saying, despite the availability of AAC, hinders the right to report rights violations (Pillay 2012a). Enhancing reciprocal communication - realising the right to be understood - can raise self-advocacy opinions and reduce continuous victimisation (Bornman et al. 2011).

\section{Competence and capacity}

Where competence relates to the ability to do something successfully or efficiently, capacity speaks to legal independence and participation during legal proceedings (UN 2006). Having one's experiences and accounts of events received in a court of law, for example, is important for building competence (Bornman et al. 2011; Mckenzie 2013; Nash \& Navias 1992).

Competence: Environmental challenges early in life may inadvertently contribute to developing protective social maturity and competence in CWID (Pillay 2003). Such competence might assist those leaving school with transitioning into gainful work placements aimed at further skills development (Nel, Van der Westhuyzen \& Uys 2007; Van Niekerk et al. 2015).

Female learners subjected to school-based sexual violence defy misconceptions that PWID lack comprehension that their rights are violated, or lack competence to respond accordingly (Phasha \& Nyokangi 2012). Disclosures of coercion, and of being threatened and humiliated for refusing male learners' sexual advances, evince awareness of rights to bodily and psychological integrity (Phasha \& Nyokangi 2012).

Focusing only on biomedical limitations can overshadow individual competencies, lower expectations for new learning, minimise subjective experiences of living with ID and reinforce unequal power relations (Donohue \& Bornman 2014; Geiger 2012; Mckenzie \& Macleod 2012a; Young \& Berry 2016).

Capacity: Denying capacity legitimises discrimination and legally reinforces social prejudice against PWID (Pillay 2012a; UN 2006). Relative to severity level (e.g., mild, moderate, severe or profound ID), adults with mild and moderate ID can negotiate consensual sexual relationships with necessary support and guidance (Hough 2012; Phasha \& Miyaka 2014; Reinders 2008). Yet in cases of sexual violence perpetrated against PWID, the burden to prove competency that consent was refused is on the survivor with ID (Pillay 2008, 2012a, 2012b). Despite the survivor's ability to give an account, legal determination of capacity to testify against the perpetrator is ultimately out of the survivor's hands and depends on results of mental health examinations (Phaswana, Van der Westhuizen \& Krüger 2013; Pillay 2008, 2010, 2012a; Pillay \& Kritzinger 2008; Pillay \& Sargent 2000). Augmentative and alternative communication can enable courts to consider various forms of non-conventional proof of capacity and competence to give testimony (Bornman et al. 2011).

\section{Inclusive citizenship}

Citizenship provides legal status and involves participating freely in a particular national space on condition of honouring various rights and duties (Yeung, Passmore \& Packer 2008). When viewed as a politically 'unfit' homogenous group, the political rights of people with intellectual impairment are disabled in cases where individuals have competence and capacity to make political decisions (Dowse 2009; McDonagh 2008; McKenzie \& Adnams 2014; Smith, Foley \& Chaney 2008; Stein \& Stein 2007).

The medico-psychological model's prescription of special health services and protections, though warranted, risks the independence of PWID to apply their political and participatory rights as citizens with political choices (McKenzie \& MacLeod 2012b). However, equitable participation (voting), appropriate services (assistive technology) and protections (against voter intimidation) can dispel the assumption that specialist services, protections and supports are impossible to reconcile in order to realise the political rights of PWID (McKenzie \& MacLeod 2012b; Pieterse 2006).

The UNCRPD's Article 8 addresses prejudice and stereotyping, and Articles 29 and 30 pertain to political and social community participation (UN 2007). Yet, safe inclusion of PWID as members of South African communities is yet to be aligned with these principles (McKenzie, McConkey \& Adnams 2013b).

\section{Right to psychological and bodily integrity}

The second theme addresses the right to psychological and bodily integrity $(n=11)$.

Despite attempts at advancing legislation and public awareness around ID, individuals with ID appear to be easy targets for perpetrators of sexual violence. Sexual abuse of teenagers with ID is widespread, yet they experience compounded difficulties when navigating the justice system. In light of the vulnerability to sexual assault and becoming a victim of crime in South Africa, communicative capacity and being understood becomes especially important during subsequent legal proceedings

\section{Protection against abuse}

Female PWID are at increased risk of sexual abuse, that of teenagers with ID is common, and close relatives are 
implicated in most cases of sexual assaults against CWID (Bornman \& Rathbone 2016; Calitz et al. 2014; Meel 2009; Phasha 2009, 2013). Perpetuating such rights violations are misconceptions that PWID have a high sex drive, possess unusual power and feel no pain, and that sex with PWID is an act of pity and can cure the perpetrator of disease (Phasha \& Myaka 2014).

Survivors with ID are particularly vulnerable to psychological effects of sexual assault and present with higher rates of posttraumatic stress disorder and symptom intensity than ID individuals with non-sexual traumatic histories (Shabalala \& Jasson 2011). Given these increased vulnerabilities, it is unthinkable to exclude PWID from sexual education programmes (Yildiz \& Cavkaytar 2017). Without access to sexual health education, PWID will continuously struggle to protect themselves against unwanted sex, pregnancy and transmittable infections (Bornman \& Rathbone 2016; Meel 2009; Rohleder \& Swartz 2009).

Dispelling harmful misconceptions about ID and sexuality might initiate services, policies and beliefs that are more supportive of significant relationships. People with mild and moderate ID can develop meaningful sexual relationships by learning about, and consenting to and maintaining healthy sexual behaviours (Bornman \& Rathbone 2016; Kramers-Olen 2016; Phasha \& Myaka 2014; Rohleder \& Swartz 2009). Individuals with severe and profound ID will find it harder to negotiate consent around sexual practices. Interventions aimed at reducing incidence of sexual abuse of PWID can occur in formal educational and informal community settings (Phasha \& Myaka 2014). For example, traditional healers hold high esteem among many South Africans, and customary notions that jeopardise rights of PWID can be reconceptualised with these individuals (Kromberg et al. 2008; Phasha \& Myaka 2014).

\section{Right to appropriate treatment: Health, justice and well-being}

Tackling ID needs at primary health care level can advance universal services and foster integration of PWID into the national health system (Molteno, Adnams \& Njenga 2011; Petersen 2004; Pillay \& Siyothula 2011). High rates of sexual violence warrant mental and physical health interventions for PWID at primary health clinics (Phasha 2013; Shabalala \& Jasson 2011).

We appreciate that sexual assault cases involving complainants with ID challenge the South African investigative and judicial systems (Calitz 2011; Pillay \& Kritzinger 2008). Decisions about an ID survivor's ability to testify should not only depend on measures of intellectual functioning but consider self-determination as well (Phaswana et al. 2013). Appropriate mental health and legal services for ID rape survivors can aid justice and equality under the law (ss9.1 and 9.2) (RSA 1996).

The Sexual Abuse Victim Empowerment (SAVE) programme exemplifies a not-for-profit project established for complainants with ID in sexual assault cases (Dickman \&
Roux 2005). Since 1990, SAVE has advised investigators and prosecutors, addressed complaint-specific service needs like court preparation and availed expert testimony (Dickman \& Roux 2005). By 2005, conviction rates similar to the best rate for sexual assault cases in the general population were achieved (Dickman \& Roux 2005). Since then, justice for ID victims of sexual assault has lost some ground (Pillay 2012b), and the White Paper on the Rights of Persons with Disabilities admits that police lack disability service skills and have reservations about responding to complaints on behalf of PWID (Department of Social Development 2016).

\section{Right to be accommodated}

The lack of reliable and affordable public transport infrastructure and expenses incurred to access private transport, as well as the high rate of human immunodeficiency virus infection and acquired immune deficiency syndrome (HIV and AIDS) and its prioritisation in the primary health care system, serve to complicate access to state-subsidised primary care medical services throughout South Africa. The right to be accommodated $(n=8)$ speaks to subsequent access to available and appropriate services for PWID.

\section{Availability of appropriate services}

Most PWID in South Africa likely suffer poor nutrition and live in socio-economically distressed areas that further predispose them to negative outcomes (Pillay \& Siyothula 2011; Slone et al. 1998, 1999). The majority of families who care for dependent PWID rely on monthly social grants of R1600 ( \pm USD124 at the time of writing) (South African Social Security Agency 2017), and one in four families frequently go without food before their next grant pay-out (Pillay \& Siyothula 2011).

Unmet service needs of PWID combined with poverty create a dire situation for PWID (Adnams 2010; De Vries et al. 2013; McKenzie et al. 2013b; Saloojee et al. 2007; Tomlinson et al. 2014). Nonetheless, there is little evidence of service integration among South Africa's health, education and social development departments in meeting these needs (Saloojee et al. 2007), whereas the opportunity costs of informal ID care remain unrecognised (McKenzie et al. 2013b).

Further, rights concerns pertain to ill-treatment of PWID by health workers (Newton \& McGillivray 2017). Disconcertingly, primary health nurses are potential sources of support and often the first professional contact for families caring for PWID (Bornman \& Alant 2002). Ill-treatment of PWID and their caregivers could be reduced by up-skilling primary health care professionals with knowledge of ID care (Bornman \& Alant 2002). Community-based services for PWID can be supported by implementing and monitoring task-shifting of appropriate assessment, intervention and referral services (Geiger 2012; Petersen 2004; Shabalala \& Jasson 2011).

\section{Access to available services}

People with intellectual disability in South Africa remain excluded from services that could encourage their well-being 
(Adnams 2010; McKenzie, McConkey \& Adnams 2013c; Molteno et al. 2011). Children with intellectual disability, for example, are five times less likely to receive rehabilitation services than physically disabled children $(p<0.0001)$ (Saloojee et al. 2007).

Owing to funding difficulties, community homes for adults with ID focus on custodial rather than participatory socio-political practices (McKenzie et al. 2013c). Although community-based residential and occupational programmes can enable socio-economic participation (DSD 2016), the misconception that PWID are economically unviable or unable to contribute financially to their communities violates their socio-economic rights (Dowse 2009; McDonaugh 2008). Adults who contribute in the form of child care, household chores and social grants feel exploited rather than valued for their role (McKenzie 2016; McKenzie et al. 2013c).

Adults with ID who also have behavioural, physical and mental health difficulties face multiple barriers to accessing necessary services (De Vries et al. 2013; McKenzie et al. 2013b). Mentally ill PWID may experience marginalisation in an amplified manner by being sequestered as less interesting yet more bothersome members of disabling societies. Given the direction of power in such settings, any protest on their part or 'suggestions ... about care are likely to be taken as resistance or obstruction' (Tronto 2010:165), confirming their status as less than equal adults.

\section{Challenges to rights realisation}

Finally, challenges to realisation of rights $(n=4)$ warns of barriers to necessary levels and kinds of support and considers obstacles to rights implementation. People with intellectual disability struggle to exercise their constitutional rights when confronted with service barriers and low political prioritisation of care (Department of Health [DoH] n.d.; Donohue, Bornman \& Granlund 2014; Huus et al. 2015). Rights to health are hampered by shortages of professionals with ID training, unavailable medications typically indicated for treatment, obstructive referral pathways, travelling to multiple medical facilities for various interventions and poverty (Huus et al. 2015).

The majority of children with disabilities in South Africa do not attend compulsory school and a lack of clear policy constrains inclusive education (Donohue \& Bornman 2014 2015). Children with physical disabilities who also have ID will most likely be excluded from receiving assistive devices and rehabilitation (Alper \& Goggin 2017; Boot et al. 2017; Donohue et al. 2014, 2015; Saloojee et al. 2007; Spangenberg et al. 2016). Moreover, CWID are at increased risk of abandonment, abuse, multiple handicap, behaviours that challenge but may be phenotypical, co-morbid psychiatric difficulties, preventable illnesses and poor physical and dental health (De Vries et al. 2013; Dickman \& Roux 2005; Giarelli et al. 2009; Molteno et al 2001; Pillay 2012a, 2012b; Pillay \& Kritzinger 2008; Roberts et al. 2016; Van Rensburg 2007).
Most adults with ID in South Africa are cared for by family and predominantly so by women. Caregiver experiences of isolation and minimal support are common and similar across race and class (McKenzie 2016; McKenzie \& McConkey 2016). Care burdens that restrict personal growth and opportunities to pursue employment contribute to caregiver stress and pose risks to sustainable care resources (Coetzee 2015; McKenzie \& McConkey 2016).

\section{Discussion}

Underestimating pervasive ableism in South Africa trivialises the exclusion of PWID from realising their rights. Public infantilisation, abuse and taunting perpetuate the isolation of PWID who may find themselves caught between negative public perceptions and attempts at community, occupational and socio-political inclusion. South Africa's political rights (s19.3a, RSA 1996) indiscriminately entitle prison inmates to vote in elections, whereas citizens with ID face multiple barriers to exercise this right (Combrinck 2014; Hartley 2013; Kopel 2017; Ndenze 2013; Swart 2015). South Africa's 'unsound mind' aphorism maintains an outdated justification for disenfranchising PWID regardless of contemporary support (Article 29a, UN 2006) and successful suffrage elsewhere in the world (Hood 2014; Kjellberg \& Hemmingsson 2013; The Electoral Commission UK 2015).

Denial of competence and legal capacity are also fundamental ID rights violations that perpetuate discrimination and exclusion. Given contemporary interpretations of legal capacity and equality under the law (Article 12, UN 2006), the onus of proving that PWID are (un)able to participate in legal proceedings that impact their lives should be on the court - not on the survivor with ID.

People with intellectual disability are often targets of sexual violence, but obtaining justice for survivors with ID is difficult in South Africa. We thus question whether sexual assault survivors who have ID, after suffering trauma and perhaps undergoing a medico-legal examination, must undergo still further evaluations before being deemed fit to testify to their account of events (Pillay 2008). Why should rape survivors with ID have to submit to testing at all, as opposed to perpetrators proving they were unaware of their victims' intellectual impairment? Having to competently 'pass' a mental health exam prior to having capacity bestowed makes it harder for PWID to obtain justice, not easier. This approach to litigation might actually violate the dignity, equality, bodily and psychological integrity, and protection of PWID against discrimination by the state on grounds of disability (RSA 1996). Having ratified the UNCRPD (UN 2007), should the state not honour Article 12.3 and provide any means necessary to equitably meet the needs of PWID in the criminal justice system? The forensic examination of sexual assault survivors with ID should be critically (re)considered - no matter the levels of support required in the absence of mental health testing (Prinsloo 2008; Tronto 2010). 
Furthermore, justice for offenders with ID must also be considered. Offenders may understand truth, lies and moral wrongfulness but be less able to link these to real implications. Knowing right from wrong should be differentiated from successful applications of social insight and adaptive skills in appreciation of the consequences of wrongfulness. We question denying ID defendants the opportunity to testify in their own defence. A finding of intellectual impairment need not summarily disqualify one from testifying, because defendants with comparatively better adaptive than intellectual functioning can be triable (Calitz et al. 2007; Pillay 2012a, 2012b). The disenfranchising South African 'unsound mind' aphorism is again criticised, because PWID are not automatically without capacity (Combrinck 2014; Phaswana et al. 2013).

In returning to our ID definitions, legal capacity requirements that emphasise adaptive abilities might challenge a medical underscoring of intellectual deficit. Because abilities to observe, remember and communicate can be established during testimony, defendants might be enabled to give evidence - if so advised by legal representation notwithstanding conventional 'test' findings of intellectual deficit (Pillay 2008, 2012a, 2012b; Pillay \& Kritzinger 2008).

Thus far, we have commented on the vulnerability of PWID who are victims and perpetrators of crimes. But what of any adults with ID in South Africa? By interpreting the United Nations Convention on the Rights of the Child (UNCRC) (UN 1989), the protection of vulnerable children is legislated in South Africa's Children's Act (38 of 2005, Department of Justice [DoJ] 2005). Consequently, the departments of Social Development and Health are legally required to intervene on behalf of children at risk. The Mental Healthcare Act (DoH Act 17 of 2002) and General Regulation Amendment (DoH 2016) supports institutional state care for adults with severe and profound ID, but lacks rights governance for adults with any severity of ID living in community settings. Beyond the inadequate Mental Healthcare Act (DoH 2002) or even the Older Persons Act 13 (DoJ 2006), no act similar to the Children's Act (DoJ 2005) intervenes on behalf of vulnerable adults with ID at risk of rights abuses and death (Makgoba 2016).

In light of the lacking legislation as discussed above, we turn to the Esidimeni care crisis, violations of the constitutional right to life (RSA 1996) and the urgency of purposeful community safety requirements of PWID. The Esidimeni crisis started in 2016 and marks the deaths of more than 140 adults in community care after being discharged from a specialist care facility by the Gauteng Health Department (Bornman 2017; Lund 2016; Rahlaga 2017; Tlhabye 2017). Although at least half of the deceased lived with ID in the absence of psychiatric illness, a well-intended Ombud report (Makgoba 2016) obscured distinctions between mental illness and ID and thus dismissed the particular vulnerabilities and service needs of individuals who live with either or both. With no statutory framework or legislated minimum threshold of community care to answer to yet, the state currently maintains no legal obligation to perform adequate safeguarding of adults with ID.

Despite deinstitutionalisation, PWID remain isolated from communities in which they feel victimised, rarely participate in basic education and skills development programmes and struggle to find appropriate work placements without help. The need remains for protective and participatory communitybased services, but these must be developed and monitored in line with purposeful care and safe community inclusion. This is particularly urgent as results have shown. When family caregivers burn out or die, PWID are left with limited options. Few relatives or neighbours willingly take on the support needs of PWID (Geiger 2012), whereas community care facilities are in short supply and have years-long waiting lists.

As it is the right to inclusion of every person in South Africa, PWID should also be able to have their health needs initially assessed or met at primary health care level, yet are often redirected to specialist settings for services that could have been delivered at their local clinics. In the same vein, a lack of ID awareness at primary care level results in PWID getting lost to referral services in cases where they should have been receiving specialist intervention.

We end this discussion by suggesting that one way to reduce discrimination against PWID is to encourage equitable practices that include and rely on the expertise of people living with ID. In just societies that celebrate self-determination, assistance is commonplace, and barriers to developing adaptive abilities are removed to increase competency.

\section{Practical implications}

In returning to our aims and objectives, we now see that PWID in South Africa face more difficulties than the general population when attempting to access justice, health, educational, employment and social services. Prejudice increases violence against PWID, but negative bias excludes them from public health and safety campaigns. There is a need to address such discrimination through advocacy interventions similar to those employed in other national rights campaigns, like the HIV/AIDS Treatment Action Campaign $^{4}$ (tac.org.za).

Legislation for vulnerable adults with ID is yet to be advocated for and taken up in protections, services and policies in South Africa. An adult at risk is any person who is aged 18 years or over and at risk of abuse or neglect because of their needs for care or support. We can cautiously turn to just as recent European examples of the United Kingdom Care Act (DoH UK 2014), Safeguarding Policy of the Office of the Public Guardian (Office of the Public Guardian England and Wales 2015), Vulnerable Adults Act Draft Bill (Government of Singapore 2016), Protection of Vulnerable Adults from Financial

4.The Treatment Action Campaign (TAC) started campaigning in South Africa for access to AIDS treatment in December 1998. It has since become one of the most access to AIDS treatment in December 1998. It has since become one of the most impactul civil society organisations working on AIDS in the Global South. By 2002, it successfully campaigned the Constitutional Court to order the South African government to provide anti-retroviral drugs to prevent vertical transmission of HIV from mothers to infants during birth. 
Exploitation Act (Alabama Securities Commission 2016) and the Adult Protective Services Act (State of Illinois Department on Aging 2013). These examples share the common goal of preventing harm and reducing the risk of abuse or neglect to adults with care and support needs, and safeguarding adults in ways that support them in making choices and having control in how they choose to live their lives. In South Africa, such legislation can raise public awareness so that individuals and communities can play their part in preventing, identifying and responding to the abuse and neglect of vulnerable adults living with ID.

We all require opportunities to realise our constitutional rights. People with intellectual disability require encouragement to participate in the socio-political lives of their communities, whatever forms these take. Sufficient support will exceed minimal levels but must be provided - whether these offers are taken up will remain every individual's choice, but must be made available (Stein \& Stein 2007; Tronto 2010). Exercising ID rights implies negotiating not only with individuals who aim to support ID voices, dismantle restrictions and develop political behaviours but also with those who prefer to maintain barriers. Because compliance and resistance to inclusive processes can be expected, self-advocacy groups and local ID organisations must be sustained.

Students from various disciplines enthusiastic about working with PWID will be better prepared for meeting ID care needs if trained as integrated practitioners (Geiger 2012; Roberts et al. 2016). Instructors with ID can broaden practitioner understanding, and future service designs can integrate the experience of PWID and their caregivers (Grut et al. 2012). Continuous professional development and journal clubs can keep practitioners current on best practice (Donohue \& Bornman 2015).

Rights realisations for PWID requires eliminating stigma, encouraging inclusive practices, opportunities for occupational skills development, access to job coaching and supportive employers and pathways out of poverty. Dispelling stereotypes and presumptions, campaigning for quality primary ID health care, advocating for legislative support and lobbying political will could reduce the risk of life-threatening discrimination against PWID (Makgoba 2016).

\section{Implications for research}

South African ID rights researchers have aligned their arguments with the Bill of Rights (RSA 1996) and global disability initiatives like the UNCRPD (Drew et al. 2011; UN 2006). Knowledge on ID is still predominantly located in non-intellectually impaired individuals, mostly at universities from which PWID are excluded. If projects are not driven by people with intellectual impairment, their experiences of disablement must at least be included during service development and research planning phases.

Although inclusive research locates PWID as co-researchers, emancipatory research encourages principle researchers with
ID to select topics, collect and analyse data and publish in accessible journals with necessary support as required. Both approaches can realise the right of PWID to create and claim knowledge on ID matters (Capri \& Coetzee 2012). Consulting with self-advocates and researchers with ID can not only change the way ID is understood and responded to in South Africa but also collect opinions of PWID on issues that affect their lives directly.

Rights issues that received the least amount of research attention throughout the 25-year review period include the right to be understood $(n=4)$ and the lack of appropriate services $(n=2)$. The right to socio-political participation and inclusive citizenship requires urgent investigation $(n=1)$. There are opportunities for researching the experiences and attitudes of primary health care workers towards PWID and for addressing a lack of South African evidence regarding support and interventions for offenders with ID. The sexual rights and health of PWID, and rights to parent, can be included as neglected fields of study and advocacy.

\section{Limitations}

We aimed to describe published studies on advocacy, addressing stigma and promoting ID rights and awareness in South Africa. It is beyond the scope of this review to include work on ID in South Africa that has not been published in peer-reviewed journals (i.e. 'grey literature'), and this limitation can contribute to publication bias.

Although arguments on therapeutic sterilisation were rationally and logically presented by Nash and Navias (1992) over two decades ago, it must be noted that the context of sterilisation of PWID in South Africa has changed significantly since 1992. The authors uncritically argue that persons with mild ID would not be able to provide consent for sterilisation. The findings of this particular article might have been acceptable at the time, but are certainly not tolerable in 2017 (at the time of writing), and it is doubtful whether it would garner support from current clinicians in the field.

Donohue et al. (2014) recognise that their results are limited by the sample of CWID selected to participate in their study and that their findings cannot be generalised as representative of experiences of all CWID in South Africa. Despite inclusive education service delivery problems, we must highlight that there are approximately 423 schools for LSENs in South Africa.

\section{Conclusion}

Our scoping review investigated pertinent issues relating to the rights of PWID in South Africa. We incorporated available research evidence in a synopsis of 59 eligible studies, addressed implications for practice and identified areas for future investigation. Realising the rights of PWID in South Africa to participate as socio-political equals, access services, own their psychological and bodily integrity, and move freely without discrimination is an ongoing project. 
Barriers to exercising these rights were highlighted. Research evidence advocates that - for a start - the rights and needs of PWID be taken up with serious commitment by the South African state, its legislature and public service departments. Statutory obligations to protect and realise the rights of any South African must extend to PWID and their supporters who are forging ahead in a disabling and service constrained socio-political environment.

Turning back to the continuum of 'changing states of impairment and health' (Swartz et al. 2012:1), Kittay et al.'s (2005) myth of independence helps us realise that being human can be defined not by commonly shared characteristics (e.g. high-level cognitive functioning), but by what all human beings are not. We are not immune to the injurious fragility of bone and brain, we are not of able mind and body permanence and we are ultimately never independent.

Although still occupying a space on the fairly healthy end of Swartz et al.'s (2011) continuum, we may find it difficult to imagine ourselves in a future impaired, ill or injured state. But we must take cognisance of a universal human frailty so that we can face our own inescapable fragility with dignity and justice, secure in the protection against violence of moral, psychological and physical abuse.

\section{Acknowledgements}

We acknowledge the authors who contributed their research to this scoping review. We also acknowledge the work undertaken by the broader disability community on a daily basis. Thanks to Marleen van Wyk for assisting us as subject librarian. Many thanks to Leslie Swartz ( $\mathrm{PhD}$, Emeritus Professor), Colleen Adnams (FCPaed) and Peter Smith (FCPsych) for their guidance. Thank you to Lorna Kwint and the anonymous reviewers for their helpful comments, and to Martha Geiger, our editor.

\section{Competing interests}

This project was made possible, in part, with assistance from the Vera Grover Scholarship Fund. The authors declare that they have no financial or personal relationships that may have inappropriately influenced them in writing this article. None of the review authors received remuneration for their contribution, nor did any pay to participate in this scoping review.

\section{Authors' contributions}

C.C. was the principle investigator and contributed to study conceptualisation, methodology development, data analysis, critical analysis and review, visualising the work, writing the original draft and presenting the work. L.A. contributed as rater and reviewer to data analysis, critical analysis, review of the manuscript, commentary and revision. J.M. and O.C. contributed to data analysis as both raters and reviewers, and to manuscript review. S.M. contributed to data analysis as reviewer. M.S. and A.H. contributed as independent raters.
L.S. contributed to study conceptualisation and verification. P.S. and C.A. contributed to data verification.

\section{References}

Adnams, C.M., 2010, 'Perspectives of intellectual disability in South Africa: Epidemiology, policy, services for children and adults', Current Opinion in Psychiatry 23(5), 436-440. https://doi.org/10.1097/YCO.0b013e32833cfc2d

Alabama Securities Commission, 2016, Protection of vulnerable adults from financia exploitation act 2016, viewed 01 November 2016, from http://asc.alabama.gov/ News $/ 2016 \% 20$ News/4-18-16\%20Protection $\% 20$ of\%20Vulnerable $\% 20$ Adults\%20Act\%202016.pd

Ali, A., Kock, E., Molteno, C., Mfiki, N., King, M. \& Strydom, A., 2015, 'Ethnicity and selfreported experiences of stigma in adults with intellectual disability in Cape Town South Africa', Journal of Intellectual Disability Research 59(6), 530-540. https://doi. org/10.1111/jir.12158

Alper, M. \& Goggin, G., 2017, 'Digital technology and rights in the lives of children with disabilities', New Media \& Society 19(5), 726-740. https://doi.org/10.1177/ 1461444816686323

American Association on Intellectual and Developmental Disabilities (AAIDD), 2017, Definition of intellectual disability, viewed 03 August 2017, from http://aaidd.org/ intellectual-disability/definition\#.WZ78DSgjHIU

American Psychiatric Association (APA), 2013, Diagnostic and statistical manua of mental disorders, 5th edition: DSM-5, American Psychiatric Association, Arlington, TX.

American Psychiatric Association (APA), 2017, What is intellectual disability? viewed 03 August 2017, from https://www.psychiatry.org/patients-families/intellectualdisability/what-is-intellectual-disability

Arksey, H. \& O'Malley, L., 2005, 'Scoping studies: Towards a methodological framework', International Journal of Social Research Methodology 8(1), 19-32. https://doi. org/10.1080/1364557032000119616

Atkins, C. \& Sampson, J., 2002. 'Critical appraisal guidelines for single case study research', ECIS 2002 Proceedings, 15, 100-109.

Boot, F.H., Dinsmore, J., Khasnabis, C. \& MacLachlan, M., 2017, 'Intellectual disability and assistive technology: Opening the GATE wider', Frontiers in Public Health 5, 10. https://doi.org/10.3389/fpubh.2017.00010

Bornman, J., 2017, Life Esidimeni death toll now sits at 141, viewed 21 November 2017 from https://www.news24.com/SouthAfrica/News/life-esidimeni-death-toll-nowsits-at-141-20171013

Bornman, J. \& Alant, E., 1996, 'Nonspeaking children in schools for children with severe mental disabilities in the greater Pretoria area: Implications for speech-language therapists', The South African Journal of Communication Disorders 43, 53-61.

Bornman, J. \& Alant, E., 2002, 'Community nurses' perceptions of and exposure to children with severe disabilities and their primary caregivers', Health SA Gesondheid 7(3), 32-55. https://doi.org/10.4102/hsag.v7i3.93

Bornman, J., Nelson Bryen, D., Kershaw, P. \& Ledwaba, G., 2011, 'Reducing the risk of being a victim of crime in South Africa: You can tell and be heard', Augmentative and Alternative Communication 27(2), 17-130. https://doi.org/10.3109/0743461 8.2011.566696

Bornman, J. \& Rathbone, L., 2016, 'A sexuality and relationship training program for women with intellectual disabilities: A social story approach', Sexuality and Disability 34(3), 269-288. https://doi.org/10.1007/s11195-016-9450-z

Byrne, G., 2017, 'Prevalence and psychological sequelae of sexual abuse among individuals with an intellectual disability: A review of the recent literature', Journa of Intellectual Disabilities, e-pages 1744629517698844. https://doi.org/10.1177/ 1744629517698844

Calitz, F.J.W., 2011, 'Psycho-legal challenges facing the mentally retarded rape victim' South African Journal of Psychiatry 17(3), 66-72. https://doi.org/10.4102/ sajpsychiatry.v17i3.280

Calitz, F.J.W., De Ridder, L., Gericke, N., Pretorius, A Smit, J. \& Joubert, G., 2014 'Profile of rape victims referred by the court to the Free State Psychiatric Complex, 2003-2009', South African Journal of Psychiatry 20(1), 1-6. https://doi.org/ 2003-2009', South African Journa
10.4102/sajpsychiatry.v20i1.459

Calitz, F.J.W., Van Rensburg, P.H.J.J., De Jager, P.P., Olander, M.L., Thomas, L., Venter, R. et al., 2007, 'Psychiatric evaluation of intellectually disabled offenders referred to the Free State psychiatric complex, 1993-2003', South African Journal of Psychiatry 13(4), 147-152. https://doi.org/10.4102/sajpsychiatry.v13i4.37

Capri, C. \& Coetzee, O., 2012, 'On the unethicality of disablism: Excluding intellectually impaired individuals from participating in research can be unethical', African Journal of Disability 1(1), 1-4. https://doi.org/10.4102/ajod.v1i1.23

Carey, A.C., 2003, 'Beyond the medical model: A reconsideration of "feeblemindedness," citizenship, and eugenic restrictions', Disability \& Society 18(4), 411-430. https:// doi.org/10.1080/0968759032000080977

Carvalho-Freitas, M.N.D. \& Stathi, S., 2017, 'Reducing workplace bias toward people with disabilities with the use of imagined contact', Journal of Applied Socia Psychology 47(5), 256-266. https://doi.org/10.1111/jasp.12435

Christianson, A.L., Zwane, M.E., Manga, P., Rosen, E., Venter, A., Downs, D. et al., 2002 'Children with intellectual disability in rural South Africa: Prevalence and associated disability', Journal of Intellectual Disability Research 46, 179-186. https://doi.org/10.1046/j.1365-2788.2002.00390.x

Coetzee, O., 2015, 'Caregiving experiences of South African mothers of adults with intellectual disability who display aggression: Clinical case studies', unpublished doctoral dissertation, University of Cape Town, Cape Town. 
Combrinck, H., 2014, 'Everybody counts: The right to vote of persons with psychosocial disabilities in South Africa', African Disability Rights Yearbook 2, 75-100.

Cooke, A., Smith, D. \& Booth, A., 2012, 'Beyond PICO the SPIDER tool for qualitative evidence synthesis', Qualitative Health Research 22(10), 1435-1443. https://doi. org/10.1177/1049732312452938

Cramm, J.M., Nieboer, A.P., Finkenflügel, H. \& Lorenzo, T., 2013, 'Disabled youth in South Africa: Barriers to education', International Journal on Disability and Human Development 12(1), 31-35. https://doi.org/10.1515/ijdhd-2012-0122

Crnic, K.A., Neece, C.L., Mcintyre, L.L., Blacher, J. \& Baker, B.L., 2017, 'Intellectual disability and developmental risk: Promoting intervention to improve child and family well-being', Child Development 88(2), 436-445. https://doi.org/10.1111/ cdev. 12740

Dada, S., Huguet, A. \& Bornman, J., 2013, 'The iconicity of picture communication symbols for children with English additional language and mild intellectual disability', Augmentative and Alternative Communication 29(4), 360-373. https:// doi.org/10.3109/07434618.2013.849753

Daudt, H.M., Van Mossel, C. \& Scott, S.J., 2013, 'Enhancing the scoping study methodology: A large, inter-professional team's experience with Arksey and O'Malley's framework', BMC Medical Research Methodology 13(1), 48-56. https://doi.org/10.1186/1471-2288-13-48

Department of Health (DoH), 2002, Mental Health Care Act 17 of 2002, viewed 23 August 2017, from http://www.justice.gov.za/legislation/acts/2002-017_mentalhealthcare pdf

Department of Health (DoH) (UK), 2014, United Kingdom Care Act 2014, viewed 01 November 2016, from http://www.legislation.gov.uk/ukpga/2014/23/pdfs/ukpga 20140023_en.pdf

Department of Health (DoH), n.d., Policy guidelines: Child and adolescent mental health, viewed 01 November 2016, from https://www.health-e.org.za/wpcontent/uploads/2013/11/child_mental_health.pdf

Department of Justice (DoJ), 2005, Children's Act No. 38 of 2005, viewed 01 November 2016, from http://www.justice.gov.za/legislation/acts/2005-038\%20childrensact. pdf

Department of Justice (DoJ), 2006, Older Persons Act 13 of 2006, viewed 29 May 2017, from http://www.justice.gov.za/legislation/acts/2006-013_olderpersons.pdf

Department of Social Development (DSD), 2015, Draft first periodic country report on the United Nations Convention on the Rights of Persons with Disabilities (UNCRPD) viewed 01 November 2016, from http://www.gov.za/sites/www.gov.za/files/ Draft \%20Country\%20Report\%20on\%20the\%20CRPD\%20for\%20for\%20 Public\%20Comment\%2026\%20Nov\%202012.pdf

Department of Social Development (DSD), 2016, White paper on the rights of persons with disabilities, viewed 01 November 2016, from https://www.ru.ac.za/media/ rhodesuniversity/content/equityinstitutionalculture/documents

De Vries, P.J., Venter, A., Jacklin, L. \& Oliver, C., 2013, 'Behavioural phenotypes and neurodevelopmental disorders in Africa', Journal of Intellectual Disability Research 57(9), 793-795. https://doi.org/10.1111/jir.12070

Dickman, B.J. \& Roux, A.J., 2005, 'Complainants with learning disabilities in sexual abuse cases: A 10-year review of a psycho-legal project in Cape Town, South Africa', British Journal of Learning Disabilities 33(3), 138-144. https://doi.org/10.1111/j.14683156.2005.00355.x

Donohue, D. \& Bornman, J., 2014, 'The challenges of realising inclusive education in South Africa', South African Journal of Education 34(2), 1-14. https://doi.org/ 10.15700/201412071114

Donohue, D.K. \& Bornman, J., 2015, 'South African teachers' attitudes toward the inclusion of learners with different abilities in mainstream classrooms', Internationa Journal of Disability, Development and Education 62(1), 42-59. https://doi.org/10.1 080/1034912X.2014.985638

Donohue, D.K., Bornman, J. \& Granlund, M., 2014, 'Examining the rights of children with intellectual disability in South Africa: Children's perspectives', Journal of Intellectual and Developmental Disability 39(1), 55-64. https://doi.org/10.3109/1 3668250.2013 .857769

Donohue, D.K., Bornman, J. \& Granlund, M., 2015, 'Household size is associated with unintelligible speech in children who have intellectual disabilities: A South African study', Developmental Neurorehabilitation 18(6), 402-406. https://doi.org/10.31 09/17518423.2014.890256

Dowse, L., 2009, “'Some people are never going to be able to do that": Challenges for people with intellectual disability in the 21st century', Disability \& Society $24(5)$ 571-584. https://doi.org/10.1080/09687590903010933

Drew, N., Funk, M., Tang, S., Lamichhane, J., Chávez, E., Katontoka, S. et al., 2011 'Human rights violations of people with mental and psychosocial disabilities: An unresolved global crisis', The Lancet 378, 1664-1675. https://doi.org/10.1016/ S0140-6736(11)61458-X

Du Plessis, M., 2013, 'The social model of disability, rights discourse and the impact of South Africa's Education White Paper 6 on access to the basic education system for persons with severe or profound intellectual impairments', Law, Democracy \& Development 17, 202-225.

Emerson, E., 2007, 'Poverty and people with intellectual disabilities', Developmental Disabilities Research Reviews 13(2), 107-113. https://doi.org/10.1002/mrdd.20144

Engelbrecht, P., Oswald, M. \& Forlin, C., 2006, 'Promoting the implementation of inclusive education in primary schools in South Africa', British Journal of Special Education 33(3), 121-129. https://doi.org/10.1111/j.1467-8578.2006.00427.x

Engelbrecht, P., Oswald, M., Swart, E. \& Eloff, I., 2003, 'Including learners with intellectual disabilities: Stressful for teachers?', International Journal of Disability, Development and Education 50(3), 293-308. https://doi.org/10.1080/ 1034912032000120462
Erasmus, A., Bornman, J. \& Dada, S., 2016, 'Afrikaans-speaking parents' perceptions of the rights of their children with mild to moderate intellectual disabilities', Journal of Child Health Care 20(2), 234-242. https://doi.org/10.1177/1367493515569326

Flores, R.L., 2017, 'State reform and respect for the rights of the disabled people: A reflection on the Olmstead decision the case of New York state', Cogent Medicine 4(1), e-pages 1360542. https://doi.org/10.1080/2331205X.2017.1360542

Fujiura, G.T., Rutkowski-Kmitta, V. \& Owen, R., 2010, 'Make measurable what is not so: National monitoring of the status of persons with intellectual disability', Journal of Intellectual and Developmental Disability 35(4), 244-258. https://doi.org/10.310 9/13668250.2010.519330

Geiger, M., 2012, 'Communication training for centre-based carers of children with severe or profound disabilities in the Western Cape, South Africa', African Journal of Disability 1(1), 1-7. https://doi.org/10.4102/ajod.v1i1.10

Giarelli, E., Clarke, D.L., Catching, C. \& Ratcliffe, S.J., 2009, 'Developmental disabilities and behavioral problems among school children in the Western Cape of South Africa', Research in Developmental Disabilities 30(6), 1297-1305. https://doi. org/10.1016/j.ridd.2009.05.006

Glicksman, S., Goldberg, C., Hamel, C., Shore, R., Wein, A., Wood, D. et al., 2017 'Rights-based and person-centered approaches to supporting people with intellectual disability: A dialectical model', Intellectual and Developmental Disabilities 55(3), 181-191. https://doi.org/10.1352/1934-9556-55.3.181

Goodley, D., 2001, “'Learning difficulties," the social model of disability and impairment: Challenging epistemologies', Disability \& Society 16(2), 207-231. https://doi.org/10.1080/09687590120035816

Government of Singapore, 2016, Vulnerable adults act draft bill, viewed 01 November 2016, from file:///C:/Users/55156002/Downloads/VAA\%20Draft\%20Bill\%202016\% 20(1).pdf

Greenhalgh, T., Robert, G., Bate, P., Macfarlane, F. \& Kyriakidou, O., 2005, Diffusion of innovations in health service organisations: A systematic literature review, Blackwell Publishing, Malden, MA.

Groce, N., Kembhavi, G., Wirz, S., Lang, R., Trani, J. \& Kett, M., 2011b, Poverty and disability: A critical review of the literature in low and middle-income countries, viewed 23 August 2017, from http://www.ucl.ac.uk/lc-ccr/centrepublications/ workingpapers/WP16_Poverty_and_Disability_review.pdf

Groce, N., Kett, M., Lang, R. \& Trani, J., 2011a, 'Disability and poverty: The need for a more nuanced understanding of implications for development policy and practice', Third World Quarterly 32(8), 1493-1513. https://doi.org/10.1080/0143 6597.2011.604520

Grut, L., Braathen, S.H., Mji, G. \& Ingstad, B., 2012, 'Accessing community health services: Challenges faced by poor people with disabilities in a rural community in South Africa', African Journal of Disability 1(1), 1-7. https://doi.org/10.4102/ajod. v1i1.19

Hall, A. \& Theron, L., 2016, 'How school ecologies facilitate resilience among adolescents with intellectual disability: Guidelines for teachers', South African Journal of Education 36(2), 1-13. https://doi.org/10.15700/saje.v36n2a1154

Harden, A., 2010, 'Mixed-methods systematic reviews: Integrating quantitative and qualitative findings', Focus Technical Brief 25, 1-8.

Hartley, W., 2013, 'IEC rejects suggestions that mentally impaired be allowed to vote', Business Day, 16 September, viewed 9 May 2017, from http://www.bdlive.co.za/ national/2013/09/16/iec-rejects-suggestions-that-mentally-impaired-beallowed-to-vote

Hood, I., 2014, 'How will Scots with learning disabilities be voting in the referendum?', The Guardian, viewed 01 November 2016, from https://www.theguardian.com

Hough, R.E., 2012, 'Adult protection and "intimate citizenship" for people with learning difficulties: Empowering and protecting in light of the no secrets review', Disability \& Society 27, 131-144. https://doi.org/10.1080/09687599.2012.631802

Hughes, B., McKie, L., Hopkins, D. \& Watson, N., 2005, 'Love's labours lost? Feminism, the disabled people's movement and an ethic of care', Sociology 39(2), 259-275. https://doi.org/10.1177/0038038505050538

Human Rights Watch, 2015, South Africa: Education barriers for children with disabilities Discriminated against, excluded from schools, viewed 05 December 2016, from https://www.hrw.org/news/2015/08/18/south-africa-education-barriers-childrendisabilities

Huus, K., Dada, S., Bornman, J. \& Lygnegård, F., 2016, 'The awareness of primary caregivers in South Africa of the human rights of their children with intellectual disabilities', Child: Care, Health and Development 42(6), 863-870. https://doi. org/10.1111/cch.12358

Huus, K., Granlund, M., Bornman, J. \& Lygnegård, F., 2015, 'Human rights of children with intellectual disabilities: Comparing self-ratings and proxy ratings', Child: Care, Health and Development 41(6), 1010-1017. https://doi.org/10.1111/ cch.12244

Kamga, S.D., 2016, 'Disability rights in South Africa: Prospects for their realisation under the white paper on the rights of persons with disabilities', South African Journal on Human Rights 32(3), 569-580. https://doi.org/10.1080/02587203.201 6.1264109

Kittay, E.F., 2009, 'The personal is philosophical is political: A philosopher and mother of a cognitively disabled person sends notes from the battlefield', Metaphilosophy 40(3-4), 606-627. https://doi.org/10.1111/j.1467-9973.2009.01600.x

Kittay, E.F., Jennings, B. \& Wasunna, A.A., 2005, 'Dependency, difference and the global ethic of longterm care', Journal of Political Philosophy 13(4), 443-469. https://doi.org/10.1111/j.1467-9760.2005.00232.x

Kjellberg, A. \& Hemmingsson, H., 2013, 'Citizenship and voting: Experiences of persons with intellectual disabilities in Sweden', Journal of Policy and Practice in Intellectual Disabilities 10(4), 326-333. https://doi.org/10.1111/jppi.12056 
Kock, E., Molteno, C., Mfiki, N., Kidd, M., Ali, A., King, M. et al., 2012, 'Cross-cultural validation of a measure of felt stigma in people with intellectual disabilities', Journal of Applied Research in Intellectual Disabilities 25(1), 11-19. https://doi. org/10.1111/j.1468-3148.2011.00644.x

Kopel, C., 2017, 'Suffrage for people with intellectual disabilities and mental illness: Observations on a civic controversy', Yale Journal of Health Policy, Law, \& Ethics 17, 209-209.

Kramers-Olen, A., 2016, 'Sexuality, intellectual disability, and human rights legislation' South African Journal of Psychology 46(4), 504-516. https://doi.org/10.1177/ 0081246316678154

Kromberg, J., Zwane, E., Manga, P., Venter, A., Rosen, E. \& Christianson, A., 2008, 'Intellectual disability in the context of a South African population', Journal of Policy and Practice in Intellectual Disabilities 5(2), 89-95. https://doi.org/10.1111/ j.1741-1130.2008.00153.x

Kromberg, J.G.R., Christianson, A.L., Manga, P., Zwane, M.E., Rosen, E., Venter, A. et al., 1997, 'Intellectual disability in rural black children in the Bushbuckridge district of South Africa', Southern African Journal of Child and Adolescent Mental Health 9(1), 2-11. https://doi.org/10.1080/16826108.1997.9632485

Kruger, P., 2015, 'A critical appraisal of Western Cape forum for intellectual disability v government of the Republic of South Africa 20115 SA 87 (WCC)', Potchefstroomse Elektroniese Regsblad 18(3), 756-773. https://doi.org/10.4314/pelj.v18i3.08

Lindau, N., Amin, T., Zambon, A. \& Scior, K., 2017, 'The effect of brief digital interventions on attitudes to intellectual disability: Results from a pilot study', Journal of Applied Research in Intellectual Disabilities 31(1), 106-113. https://doi. org/10.1111/jar.12366

Lund, C., 2016, 'Mental health and human rights in South Africa: The hidden humanitarian crisis', South African Journal on Human Rights 32(3), 403-405. https://doi.org/10.1080/02587203.2016.1266799

Maclean, M.J., Sims, S., Bower, C., Leonard, H., Stanley, F.J. \& O'Donnell, M., 2017 'Maltreatment risk among children with disabilities', Pediatrics 139(4), e20161817, viewed 19 December 2016, from http://pediatrics.aappublications.org/ content/139/4/e20161817

Makgoba, M.W., 2016, The report into the circumstances surrounding the death of mentally ill patients: Gauteng Province - No guns: 94+ silent deaths and still counting, Health Ombud, Republic of South Africa, viewed 19 Decembe 2016, from https://www.sahrc.org.za/home/21/files/Esidimeni\%20full\%20 report.pdf

Maulik, P.K., Mascarenhas, M.N., Mathers, C.D., Dua, T. \& Saxena, S., 2011, 'Prevalence of intellectual disability: A meta-analysis of population-based studies', Research in Developmental Disabilities 32(2), 419-436. https://doi.org/10.1016/j.ridd. 2010.12.018

Mcdonagh, P., 2008, 'Innocence, economics and institutions: Changing the idea of idiocy in the 1840s', Journal of Intellectual Disability Research 52(8), 706.

McKenzie, J., 2013, 'Models of intellectual disability: Towards a perspective of (poss) ability', Journal of Intellectual Disability Research 57(4), 370-379. https://doi. org/10.1111/j.1365-2788.2012.01547.x

McKenzie, J., 2016, 'An exploration of an ethics of care in relation to people with intellectual disability and their family caregivers in the Cape Town metropole in South Africa', Alter 10(1), 67-78. https://doi.org/10.1016/j.alter.2015.12.001

Mckenzie, J. \& Macleod, C.I., 2012a, 'The deployment of the medico-psychological gaze and disability expertise in relation to children with intellectual disability' International Journal of Inclusive Education 16(10), 1083-1098. https://doi.org/1 $0.1080 / 13603116.2010 .540042$

Mckenzie, J. \& Macleod, C.I., 2012b, 'Rights discourses in relation to education of people with intellectual disability: Towards an ethics of care that enables participation', Disability \& Society 27(1), 15-29. https://doi.org/10.1080/0968759 9.2012.631795

McKenzie, J. \& McConkey, R., 2016, 'Caring for adults with intellectual disability: The perspectives of family carers in South Africa', Journal of Applied Research in Intellectual Disabilities 29(6), 531-541. https://doi.org/10.1111/jar.12209

Mckenzie, J., McConkey, R. \& Adnams, C., 2013a, 'Intellectual disability in Africa: Implications for research and service development', Disability \& Rehabilitation 35(20), 1750-1755. https://doi.org/10.3109/09638288.2012.751461

McKenzie, J., McConkey, R. \& Adnams, C., 2013b, 'Health conditions and support needs of persons living in residential facilities for adults with intellectual disability in Western Cape Province', South African Medical Journal 103(7), 481-484. https://doi.org/10.7196/SAMJ.6491

McKenzie, J., McConkey, R. \& Adnams, C., 2013c, 'Residential facilities for adults with intellectual disability in a developing country: A case study from South Africa', Journal of Intellectual and Developmental Disability 39(1), 45-54. https://doi.org Journal of Intellectual and Developm

McKenzie, J., Pillay, S.G., Duvenhage, C.M., Du Plessis, E. \& Jelsma, J.M., 2017 Implementation of educational provision for children with severe to profound intellectual disability in the Western Cape: From rights to reality', International intellectual disability in the Western Cape: From rights to reality', International
Journal of Disability, Development and Education 64(6), 596-611. https://doi.org/ Journal of Disability, Development

Meel, B., 2009, 'Prevalence of HIV among victims of sexual assault who were mentally impaired children ( 5 to 18 years) in the Mthatha area of South Africa', African Journal of Primary Health Care and Family Medicine 1(1), 3-5. https://doi. org/10.4102/phcfm.v1i1.5

Merrells, J., Buchanan, A. \& Waters, R., 2017, “'We feel left out": Experiences of socia inclusion from the perspective of young adults with intellectual disability', Journa of Intellectual \& Developmental Disability 1-10, viewed on 28 May 2017, from of Intellectual \& Developmental Disability 1-10, viewed on 28 May 2017, from http://www-tan
Mji, G., Rhoda, A., Statham, S. \& Joseph, C., 2017, 'A protocol for the methodological steps used to evaluate the alignment of rehabilitation services in the Western Cape, South Africa with the National Rehabilitation Policy', BMC Health Services Research 17(1), 200. https://doi.org/10.1186/s12913-017-2141-3

Moher, D., Liberati, A., Tetzlaff, J., Altman, D.G. \& The PRISMA Group, 2009, 'Preferred reporting items for systematic reviews and meta-analyses: The PRISMA statement', PLoS Medicine 6(7), e1000097. https://doi.org/10.1371/journal. pmed1000097

Molteno, C., Adnams, C. \& Njenga, F., 2011, 'Sub-specialties in psychiatry in Africaintellectual disability: Editorial', African Journal of Psychiatry 14(1), 1-3.

Molteno, G., Molteno, C.D., Finchilescu, G. \& Dawes, A.R., 2001, 'Behavioural and emotional problems in children with intellectual disability attending special schools in Cape Town, South Africa', Journal of Intellectual Disability Research 45(6), 515-520. https://doi.org/10.1046/j.1365-2788.2001.00368.x

Nash, E.S. \& Navias, M., 1992, 'The therapeutic sterilisation of the mentally handicapped. Experience with the abortion and sterilisation act of 1975 ', South African Medical Journal 82(6), 437-440.

Ndenze, B., 2013, 'Prisoners will vote in 2014 elections', IOL News, 17th September, viewed on 9 May 2017, from http://www.iol.co.za/news/crime-courts/prisonerswill-vote-in-2014-elections-1.1578772

Nel, L., Van der Westhuyzen, C. \& Uys, K., 2007, 'Introducing a school-to-work transition model for youth with disabilities in South Africa', Work 29(1), 13-18.

Nel, N., Kempen, M. \& Ruscheinski, A., 2011, 'Differentiated pedagogy as inclusive practice: The "Learn not to Burn" curriculum for learners with severe intellectual disabilities', Education as Change 15(2), 191-208. https://doi.org/10.1080/16823 206.2011.619145

Newton, D.C. \& McGillivray, J.A., 2017, 'Perspectives of carers of people with intellectual disability accessing general practice: "I'd travel to the ends of the earth for the right person"', Journal of Intellectual \& Developmental Disability 1-9, viewed on 23 September 2017, from http://www-tandfonline-com.ez.sun.ac.za/ action/doSearch?AllField=Perspectives+of+carers+of+people+with+intellectual+ disability+accessing+general+practice

Ngwena, C. \& Pretorius, L., 2012, 'Substantive equality for disabled learners in state provision of basic education: A commentary on Western Cape Forum for Intellectual Disability v government of the Republic of South Africa', South African Journal on Human Rights 28(1), 81-115. https://doi.org/10.1080/19962126.2012. 11865037

Ngwena, C.G., 2013, 'Human right to inclusive education', Netherlands Quarterly of Human Rights 31(4), 473-504. https://doi.org/10.1177/016934411303100405

Office of the Public Guardian (England and Wales), 2015, Safeguarding policy: Protecting vulnerable adults, viewed 01 November 2016, from https://www.gov. uk/government/publications/safeguarding-policy-protecting-vulnerable-adults

Officer, A. \& Shakespeare, T., 2013, 'The world report on disability and people with intellectual disabilities', Journal of Policy and Practice in Intellectual Disabilities 10(2), 86-88. https://doi.org/10.1111/jppi.12031

Peckham, N.G., 2007, 'The vulnerability and sexual abuse of people with learning disabilities', British Journal of Learning Disabilities 35(2), 131-137. https://doi. org/10.1111/j.1468-3156.2006.00428.x

Peters, M.D., Godfrey, C.M., Khalil, H., McInerney, P., Parker, D. \& Soares, C.B., 2015 'Guidance for conducting systematic scoping reviews', International Journal of Evidence-Based Healthcare 13(3), 141-146. https://doi.org/10.1097/ XEB.0000000000000050

Petersen, I., 2004, 'Primary level psychological services in South Africa: Can a new psychological professional fill the gap?', Health Policy and Planning 19(1), 33-40. psychological professional fill the gap?',
https://doi.org/10.1093/heapol/czh004

Phasha, T. \& Myaka, L., 2014, 'Sexuality and sexual abuse involving teenagers with intellectual disability: Community conceptions in a rural village of KwaZulu-Natal, South Africa', Sexuality and Disability 32(2), 153-165. https://doi.org/10.1007/ South Africa', Sexuality
s11195-014-9344-x

Phasha, T.N., 2009, 'Responses to situations of sexual abuse involving teenagers with intellectual disability', Sexuality and Disability 27(4), 187-203. https://doi. org/10.1007/s11195-009-9134-z

Phasha, T.N., 2013, 'Influences on under reporting of sexual abuse of teenagers with intellectual disability: Results and implications of a South African study', Journal of Psychology in Africa 23(4), 625-629.

Phasha, T.N. \& Nyokangi, D., 2012, 'School-based sexual violence among female learners with mild intellectual disability in South Africa', Violence against Women 18(3), 309-321. https://doi.org/10.1177/1077801212444578

Phaswana, T.D., Van der Westhuizen, D. \& Krüger, C., 2013, 'Clinical factors associated with rape victims' ability to testify in court: A records-based study of final psychiatric recommendation to court', African Journal of Psychiatry 16(5), 343348. https://doi.org/10.4314/ajpsy.v16i5.46

Pieterse, M., 2006, 'Resuscitating socio-economic rights: Constitutional entitlements to health care services', South African Journal on Human Rights 22(3), 473-502. https://doi.org/10.1080/19962126.2006.11864898

Pillay, A.L., 2003, 'Social competence in rural and urban children with mental retardation: Preliminary findings', South African Journal of Psychology 33(3), 176181. https://doi.org/10.1177/008124630303300306

Pillay, A.L., 2008, 'An audit of competency assessments on court-referred rape survivors in South Africa', Psychological Reports 103(3), 764-770. https://doi. org/10.2466/pro.103.3.764-770

Pillay, A.L., 2010, 'Intellectually disabled rape survivors' perceptions of morality and consequences of the crime', Perceptual and Motor Skills 110(3), 1119-1124. https://doi.org/10.2466/02.07.13.15.16.PMS.110.C.1119-1124 
Pillay, A.L., 2012a, 'Intellectually disabled child and adolescent sexual violence survivors face greater challenges in the legal system', Journal of Child \& Adolescent Mental Health 24(2), iii-vi. https://doi.org/10.2989/17280583.2012.735498

Pillay, A.L., 2012b, 'The rape survivor with an intellectual disability vs. the court', South African Journal of Psychology 42(3), 312-322. https://doi.org/10.1177/ 008124631204200303

Pillay, A.L. \& Kritzinger, A.M., 2008, 'Psycho-legal issues surrounding the rape of children and adolescents with mental retardation', Journal of Child \& Adolescent Mental Health 20(2), 123-131. https://doi.org/10.2989/JCAMH.2008.20.2.8.691

Pillay, A.L. \& Sargent, C., 2000, 'Psycho-legal issues affecting rape survivors with mental retardation', South African Journal of Psychology 30(3), 9-13. https://doi. org/10.1177/008124630003000302

Pillay, A.L. \& Siyothula, E.B., 2011, 'Intellectual disability examinations and social context variables among patients of low socioeconomic status', Perceptual and Motor Skills 113(2), 589-596. https://doi.org/10.2466/01.13.15.PMS.113.5.589-596

Prinsloo, J., 2008, 'In the best interest of the child: The protection of child victims and witnesses in the South African Criminal Justice System', Child Abuse Research in South Africa 9(2), 49-64.

Rahlaga, M., 2017, 'Dr Barney Selebano: Esidimeni tragedy was shameful', Eyewitness News, viewed on 15 January 2018, from http://ewn.co.za/2017/12/09/dr-barneyselebano-esidimeni-tragedy-was-shameful

Reinders, H.S., 2008, 'Persons with disabilities as parents: What is the problem?' Journal of Applied Research in Intellectual Disabilities 21, 308-314. https://doi. org/10.1111/j.1468-3148.2008.00445

Republic of South Africa, 1996, Constitution of the Republic of South Africa: Chapter 2 The Bill of Rights, Act No. 108 of 1996, viewed 06 March 2017, from https:// www.westerncape.gov.za/legislation/bill-rights-chapter-2-constitution-republicsouth-africa

Rhodes University, 1969/2017, Dictionary Unit for South African English, viewed 06 March 2017, from https://www.ru.ac.za/dsae/

Roberts, T., Chetty, M., Kimmie-Dhansay, F., Fieggen, K. \& Stephen, L.X.G., 2016, 'Dental needs of intellectually disabled children attending six special educational facilities in Cape Town', South African Medical Journal 106(6), 94-97. https://doi. org/10.7196/SAMJ.2016.v106i6.11006

Robertson, J., Hatton, C., Emerson, E. \& Yasamy, M.T., 2012, 'The identification of children with, or at significant risk of, intellectual disabilities in low-and middleincome countries: A review', Journal of Applied Research in Intellectual Disabilities 25(2), 99-118. https://doi.org/10.1111/j.1468-3148.2011.00638.x

Rohleder, P. \& Swartz, L., 2009, 'Providing sex education to persons with learning disabilities in the era of HIV/AIDS', Journal of Health Psychology 14(4), 601-610. disabilities in the era of HIV/AIDS', Journal of
https://doi.org/10.1177/1359105309103579

Roozen, S., Peters, G.J.Y., Kok, G., Townend, D., Nijhuis, J. \& Curfs, L., 2016, 'Worldwide prevalence of fetal alcohol spectrum disorders: A systematic literature review including meta-analysis', Alcoholism: Clinical and Experimental Research 40(1) 18-32. https://doi.org/10.1111/acer.12939

Roy, A., Roy, A. \& Roy, M., 2012, 'The human rights of women with intellectua disability', Journal of the Royal Society of Medicine 105(9), 384-389. https://doi. org/10.1258/jrsm.2012.110303

Royal College of Psychiatrists (RCP), 2001, Diagnostic criteria for psychiatric disorders for use with adults with learning disabilities/mental retardation, Gaskell, London.

Saloojee, G., Phohole, M., Saloojee, H. \& IJsselmuiden, C., 2007, 'Unmet health, welfare and educational needs of disabled children in an impoverished South African peri-urban township', Child: Care, Health and Development 33(3), 230-235. https://doi.org/10.1111/j.1365-2214.2006.00645.x

Selb, M., 2017, ICF case studies translating interventions into real-life gains: A rehab cycle approach, viewed 20 August 2017, from https://www.icf-casestudies.org/ en/introduction/introduction-to-the-icf/the-integrative-bio-psycho-social-modelof-functioning-disability-and-health

Shabalala, N. \& Jasson, A., 2011, 'PTSD symptoms in intellectually disabled victims of sexual assault', South African Journal of Psychology 41(4), 424-436. https://doi. org/10.1177/008124631104100403

Shakespeare, T., 2017, 'Critiquing the social model', in E. Emens \& M. Stein (eds.), Disability and equality law, pp. 67-94, Routledge, London.

Slone, M., Durrheim, K., Kaminer, D. \& Lachman, P., 1999, 'Issues in the identification of comorbidity of mental retardation and psychopathology in a multicultural context', Social Psychiatry and Psychiatric Epidemiology 34(4), 190-194. https:// context', Social Psychiatry and Psych
doi.org/10.1007/s001270050132

Slone, M., Durrheim, K., Lachman, P. \& Kaminer, D., 1998, 'Association between the diagnosis of mental retardation and socioeconomic factors', American Journal on Mental Retardation 102(6), 535-546. https://doi.org/10.1352/0895-8017(1998) 102\%3C0535:ABTDOM\%3E2.0.CO;2

Smith, L., Foley, P.F. \& Chaney, M.P., 2008, 'Addressing classism, ableism, and heterosexism in counselor education', Journal of Counseling and Development 86(3), 303-309. https://doi.org/10.1002/j.1556-6678.2008.tb00513.x

South African Social Security Agency, 2017, Social grants, viewed 13 August 2017 from http://www.sassa.gov.za/index.php/social-grants

Spangenberg, K., Van Rensburg, W., Kilian, E., Vorster, H., Corten, L., McKenzie, J. et al., 2016, 'The validation of an educational database for children with profound intellectual disabilities', African Journal of Disability 5(1), 1-11. https://doi.org/ 10.4102/ajod.v5i1.237
State of Illinois Department on Aging, 2013, Adult protective services act 2013, viewed 01 November 2016, from https://www.illinois.gov/aging/Resources/NewsAnd Publications/Publications/Documents/APS\%20Act\%20Book2013.pdf

Statistics South Africa (SSA), 2014, Census 2011: Profile of persons with disabilities in South Africa, viewed 21 August 2015, from http://www.statssa.gov.za/publications/ Report-03-01-59/Report-03-01-592011.pdf

Stein, M.A. \& Stein, P.J., 2007, 'Beyond disability civil rights', Hastings Law Journa 1203-1240, viewed 21 August 2015, from http://digitalcommons.ilr.cornell.edu/ cgi/viewcontent.cgi?article $=1336 \&$ context $=$ gladnetcollect

Swart, M., 2015, 'The prisoner voting dilemma: A comparison between the position in the United Kingdom and South Africa', Journal of South African Law 2015(4), 706-718.

Swartz, L., 2010, Able-bodied: Scenes from a curious life, Zebra Press, Cape Town.

Swartz, L., Van Der Merwe, A., Buckland, A. \& McDougall, K., 2012, 'Producing boundary-breaking texts on disability issues: The personal politics of collaboration' Disability \& Rehabilitation 34(11), 951-958. https://doi.org/10.3109/09638288.2 011.624248

The Electoral Commission (UK), 2015, Voters with a disability are reminded there should be no barriers to them casting their vote on 7 May, viewed 01 November 2016, from http://www.electoralcommission.org.uk

The United Nations (UN), 1989, United Nations Convention on the Rights of the Child viewed 01 November 2016, from http://srsg.violenceagainstchildren.org/sites/ default/files/documents/docs/A-RES-44-25_EN.pdf

The United Nations (UN), 2006, United Nations Convention on the Rights of People with Disabilities (UNCRPD) A/RES/61/106, viewed 19 December 2016, from $\mathrm{http}: / /$ www.un.org/disabilities/documents/convention/convoptprot-e.pdf

Thornicroft, G., Rose, D., Kassam, A. \& Sartorius, N., 2007, 'Stigma: Ignorance, prejudice or discrimination?', The British Journal of Psychiatry 190(3), 192-193. https://doi. org/10.1192/bjp.bp.106.025791

Thabye, G., 2017, 'Esidimeni: They died from cold and hunger', IOL News, viewed on 09 May 2017, from https://www.iol.co.za/capetimes/news/esidimeni-they-diedfrom-cold-and-hunger-2097593

Tomlinson, M., Yasamy, M.T., Emerson, E., Officer, A., Richler, D. \& Saxena, S., 2014 'Setting global research priorities for developmental disabilities, including intellectual disabilities and autism', Journal of Intellectual Disability Research 58(12), 1121-1130. https://doi.org/10.1111/jir.12106

Tronto, J.C., 2010, 'Creating caring institutions: Politics, plurality, and purpose', Ethics and Social Welfare 4(2), 158-171. https://doi.org/10.1080/17496535.2010.484259

Urban, M., Chersich, M.F., Fourie, L., Chetty, C., Olivier, L. \& Viljoen, D., 2008, 'Fetal alcohol syndrome among grade 1 schoolchildren in Northern Cape province: Prevalence and risk factors', South African Medical Journal 98(11), 877-882.

Van Niekerk, L., Coetzee, Z., Engelbrecht, M., Hajwani, Z. \& Terreblanche, S., 2015, 'Time utilisation trends of supported employment services by persons with mental disability in South Africa', Work 52(4), 825-833. https://doi.org/10.3233/ WOR-152149

Van Rensburg, A.J., 2007, 'Long-term care of children and adolescents with intellectual disabilities and severe physical abnormalities', Journal of Child \& Adolescent Mental Health 19(2), 115-121. https://doi.org/10.2989/17280580709486646

Wilson, N.J., Jaques, H., Johnson, A. \& Brotherton, M.L., 2017, 'From social exclusion to supported inclusion: Adults with intellectual disability discuss their lived experiences of a structured social group', Journal of Applied Research in Intellectual Disabilities 30(5), 47-858. https://doi.org/10.1111/jar.12275

Wissink, I.B., Van Vugt, E.S., Smits, I.A., Moonen, X.M. \& Stams, G.J.J., 2017, 'Reports of sexual abuse of children in state care: A comparison between children with and without intellectual disability', Journal of Intellectual \& Developmental Disability without intellectual disability', Journal of Intellectual \& Developmental Disability
$1-12$, viewed on 26 April 2017, from http://www-tandfonline-com.ez.sun.ac.za/ 1-12, viewed on 26 April 2017, from http
doi/full/10.3109/13668250.2016.1269881

World Bank, 2017, South Africa overview: World Bank Group, viewed 07 August 2017 from http://www.worldbank.org/en/country/southafrica/overview

World Health Organization (WHO), 2002, Towards a common language for functioning, disability and health: The International Classification of Functioning, Disability and Health (ICF), viewed 21 November 2017, from http://www.who.int/classifications/ icf/icfbeginnersguide.pdf

World Health Organization (WHO), 2011, World report on disability, World Health Organization, Geneva.

World Health Organization (WHO) \& World Bank, 2011, World report on disability, viewed 07 August 2017, from http://www.who.int/disabilities/world_report/2011/ report.pdf

Yeung, P.H., Passmore, A.E. \& Packer, T.L., 2008, 'Active citizens or passive recipients: How Australian young adults with cerebral palsy define citizenship', Journal of Intellectual and Developmental Disability 33(1), 65-75. https://doi.org/10.1080/ 13668250701875129

Yildiz, G. \& Cavkaytar, A., 2017, 'Effectiveness of a sexual education program for mothers of young adults with intellectual disabilities on mothers' attitudes toward sexual education and the perception of social support', Sexuality and Disability 35(1), 3-19. https://doi.org/10.1007/s11195-016-9465-5

Young, L.S. \& Berry, J., 2016, 'Slipping and holding minds: A psychosocial analysis of maternal subjectivity in relation to childhood disability', African Journal of Disability 5(1), 1-9. 